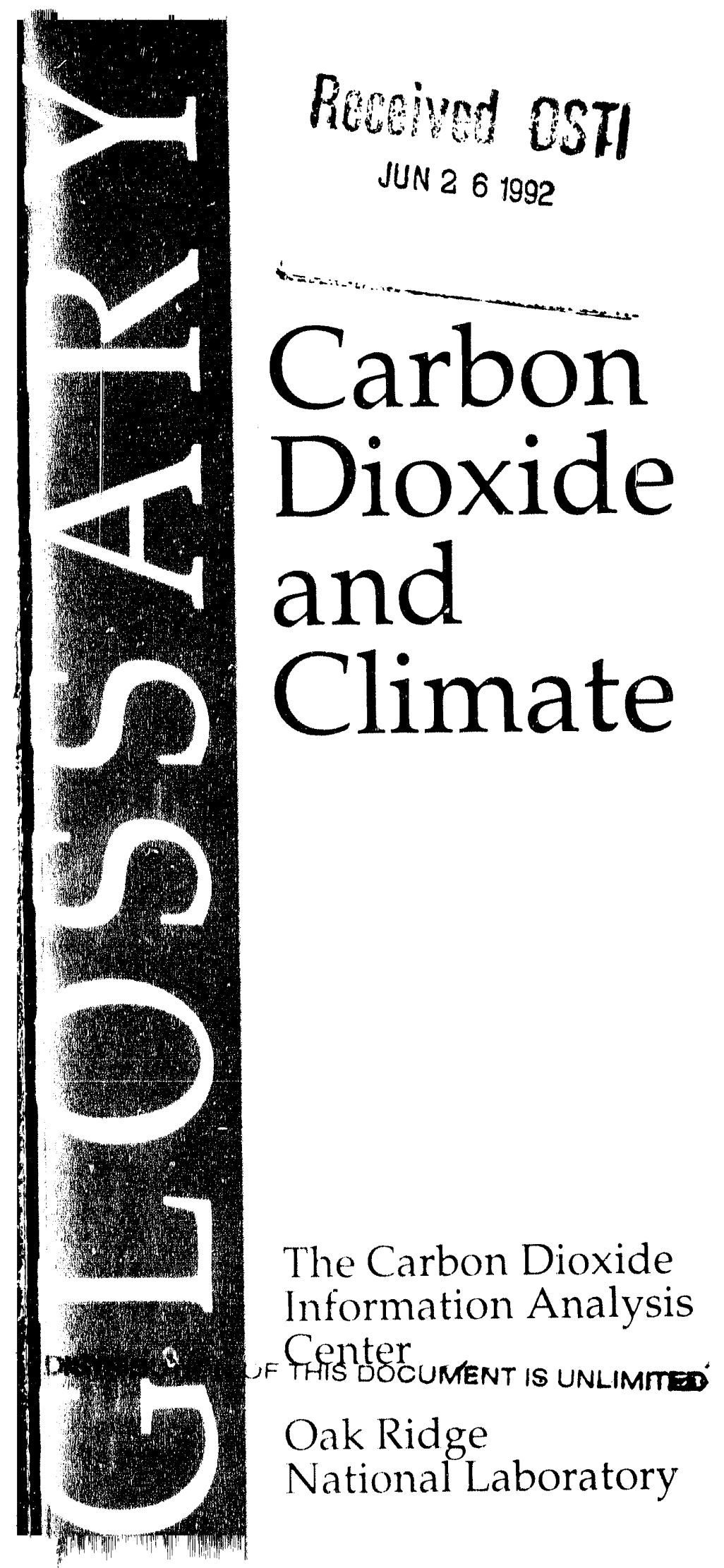




\section{GLOSSARY: Carbon Dioxide and Climate}

Carbon Dioxide Information Analysis Center

Sponsored by the U.S. Department of Energy Atmospheric and Climate Research Division Carbon Dioxide Research Program

Environmental Sciences Division Publication No. 3532

August 1990

Oak Ridge National Laboratory

Oak Ridge, Tennessee 37831-6335 operated by

Martin Marietta Energy Systems, Inc. for the

U.S. DEPARTMENT OF ENERGY under Contract No. DE-AC05-84OR21400

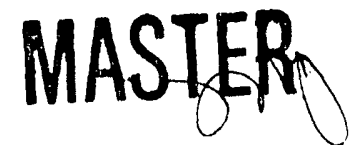




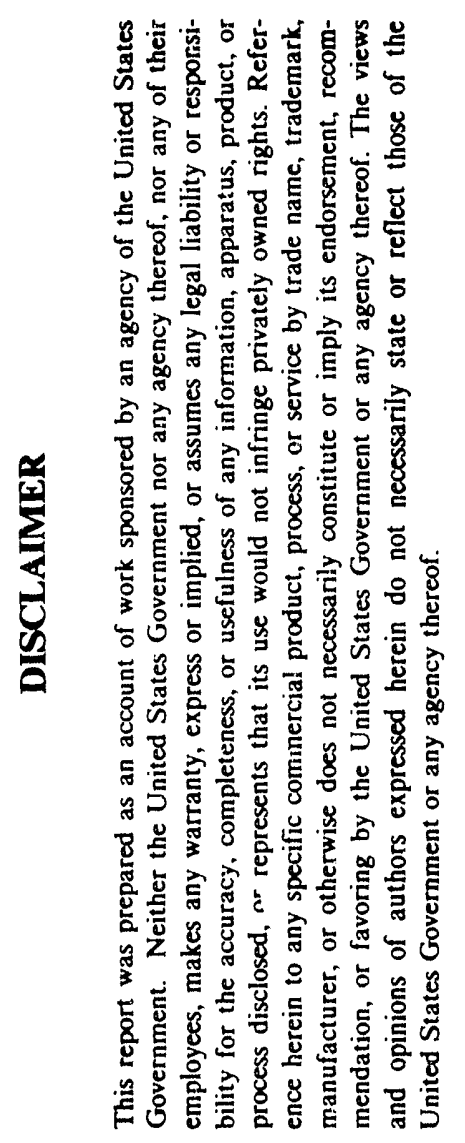




\section{Table of Contents}

Introduction $\ldots \ldots \ldots \ldots \ldots \ldots \ldots \ldots \ldots$

Acknowledgments .................. 3

Glossary ................... 5

Tables ........................ 41

International System of Units (SI): Prefixes ....41

Useful Quantities in $\mathrm{CO}_{2}$ Research ........ 42

Common Conversion Factors ............ 43

Common Energy Unit Conversion Factors . . . . . 44

Geologic Time Scales . . . . . . . . . . . . . . . . 45

Factors and Units for Calculating Annual $\mathrm{CO}_{2}$ Emissions Using Global Fuel Production Data ........................46

Some Abbreviations and Acronyms

Commonly Used in $\mathrm{CO}_{2}$ Research . . . . . . . . 47

References ..........................49

Appendix: Carbon Dioxide Information

Analysis Center 


\section{INTRODUCTION}

This Glossury contains definitions of selected $\mathrm{CO}_{2}$-related terms as well as tables containing information related to $\mathrm{CO}_{2}$ and climate. Each term is defined with an emphasis on its relationship to $\mathrm{CO}_{2}$ and climate. Many of the definitions are then followed by a more detailed description of the term and its use. References to the literature from which the definitions were taken are listed at the end of the Glossary.

This is the third edition of the Glossary. The first edition was compiled by Julia A. Watts, Environmental Sciences Division, Oak Ridge National Laboratory. The second was compiled by Raymond E. Millemann. This edition was compiled by F. M. O'Hara, Jr. Much thanks is due them for their contributions to the current edition.

The new edition includes redefinitions of many of the original terms, the addition of more than a hundred new terms, and updating and expansion of the section of tables.

Citation of this document: Glossary: Carbon Dioxide and Climate, ORNL/CDIAC-39, Oak Ridge National Laboratory, Oak Ridge, Tennessee (Aug. 1990). 


\section{ACKNOWLEDGMENTS}

We are grateful to the following individuals for their critial reviews of this and/or earlier editions of the Glossary: ubert M. Cushman, Michael P. Farrell, Paul Kanciruk, (regg Marland, Richard J. Norby, Tsung-Hung Peng, V. Mac Post, and John R. Trabalka, Environmental Sciences D ision, Oak Ridge National Laboratory; Roger C. Dahl$m \varepsilon$, Thomas J. Gross, and Michael R. Riches, U.S. Departme it of Energy, Carbon Dioxide Research Program; James A. Edionds, Pacific Northwest Laboratory; Michael C. MacCreslken and Karl Taylor, Lawrence Livermore National Lab atory; Mark F. Meier, INSTAAR, University of Coloriıdo; Mark Steinberg, Wisconsin Electric Power Compang: and Meyer Steinberg, Brookhaven National Laboratory. 


\section{GLOSSARY}

ablation (glacial)-All processes, which include meiting, evaporation (sublimation), wind erosion, and calving (breaking off of ice masses), that remove snow or ice from a glacier or snowfield. The term also refers to the amount of snow or ice removed by these processes. [101, 102]

abscission-Shedding by a plant of its parts, such as leaves, flowers, fruits, or seeds. The process is regulated by the plant hormone abscisic acid. [100]

absorption coefmcient--A measure of the amount of radiant energy, incident normal to a planar surface, that is absorbed per unit distance or unit mass of a substance. $[105,127]$

acclimation (acclimatization)-Change that occurs in an organism to allow it to tolerate a new environment. [104]

accumulation (glacial)-All processes, which include snowfall, condensation, avalanching, snow transport by wind, and freezing of liquid water, that add snow or ice to a glacier, floating ice, or snow cover. The term also includes the amount of snow or other solid precipitation added to a glacier or snowfield by these processes. [10\%]

acidity proflle--The acid concentration in ice core layers as a function of depth as determined from electrical measurements. The magnitudes of some volcanic eruptions in the Northern Hemisphere have been estimated from the acidity of annual layers in ice cores taken in Greenland. This methodology is sometimes referred to as "acidity signal" or "acidity record. ${ }^{n}[1,2]$

adsptation-The adjustment of an organism or population to a new or altered environment through genetic changes brought about by natural selection. [100]

adiabatic process - A thermodynamic change of state of a system such that no heat or mass is transferred across the boundaries of the system. In an adiabatic process, expansion always results in cooling, and compression in warming. [3]

adiabatic warming-See adiabatic process.

adrection-The predominately horizontal large-scale movement of air that causes changes in temperature or 
other physical properties. In oceanography, advection is the horizontal or vertical flow of sea water as a current. [3]

gerosol-Particulate material, other than water or ice, in the atmosphere ranging in size from approximately $10^{3}$ to larger than $10^{2} \mu \mathrm{m}$ in radius. Aerosols are important in the atmosphere as nuclei for the condensation of water droplets and ice crystals, as participants in various chemical cycles, and as absorbers and scatterers of solar radiation, thereby influencing the radiation budget of the earthatmosphere system, which in turn influences the climate on the surface of the Earth. [4]

agglomeration-In meteorology, the process by which precipitation particles grow larger by collision or contact with cloud particles or other precipitation particles. [140]

Agung-- Sctive volcano $10,380 \mathrm{ft}(3,141 \mathrm{~m})$ high in Bali, Indonesia. Last eruption was in 1964. [112]

airborne fraction--The portion of $\mathrm{CO}_{2}$ released from all energy consumption and land use activities that remains in the atmosphere as opposed to the amounts absorbed by plants and oceans. How the world's total carbon is partitioned among the oceanic, terrestrial, and atmospheric pools is determined by complex biogeochemical and climatological interactions. [121]

airborne particulates-Total suspended mat:er found in the atmosphere as solid pieces or liquid droplets. Airborne particulates include windblown dust, emissions from industrial processes, smoke from the burning of wood and coal, and the exhaust of motor vehicles. [140]

airmass - $A$ widespread body of the atmosphere that gains certain meteorological or polluted characteristics while set in one location. The characteristics can change as it moves away. [140]

albedo-The fraction of the total solar radiation incident on a body that is reflected by it. [5]

Alfisols - An order of soils with a medium-to-high base supply, horizons of clay accumulation, and gray-brown surface horizons. [100]

algae-Simple rootless plants that grow in sunlit waters in relative proportion to the amounts of nutrients available. They are food for fish and small aquatic animals. [140] 
algal blooms-Sudden spurts of algal growth that can indicate potentially hazardous changes in local water chemistry. [140]

alkalinity-A pressure- and temperature-independent property of seawater that determines in part the carbon content of seawater. Carbonate alkalinity is the sum of the concentration of bicarbonate plus two times the concentration of the carbonate ions. Total alkalinity is the amount of acid required to bring seawater to a $\mathrm{pH}$ at which all dissolved inorganic carbon becomes freely exchangeable. The alkalinity of the oceans is determined with potentiometric or normal titration techniques that detect and measure the presence of bicarbonate, carbonate, and borate ions. $[6,7,8]$

altithermal period-A A period of high temperature, particularly the one from 8000 to 4000 B.P. (before the present era), which was apparently warmer in summers, as compared with the present, and with the precipitation zones shifted poleward. Also called the hypsithermal period. $[100,107]$

anadromous--Fish that spend their adult lives in the sea but swim upriver to freshwater spawning grounds to reproduce. [140]

analog (climate)-A large-scale weather pattern of the past that is similar to a current situation in its essential characteristics. [100]

Antarctic Ice Sheet--See ice sheet

anthropogenic-Man made. Usually used in the context of emissions that are produced as the result of human activities. [138]

anticyclone (high-pressure area)-An atmospheric highpressure closed circulation with clockwise rotation in the Northern Hemisphere, counterclockwise in the Southern Hemisphere, and undefined at the Equator. [100]

aragonite- $A$ mineral species of calcium carbonate $\left(\mathrm{CaCO}_{3}\right)$ with a crystal structure different from that of vaterite and calcite, which are the other two forms of $\mathrm{CaCO}_{3}$. It is precipitated from ocean surface waters mainly by organisms (e.g., coral) that use it to make their shells and skeletons. $[100,108]$

Arctic haze-A persistent winter diffuse layer in the Arctic atmosphere whose origin may be related to longange transport of midlatitude continental manmade pollutants. [109] 
atmosphere (An)-A standard unit of pressure representing the pressure exerted by a 29.92 -in. column of mercury at sea level at $45^{\circ}$ latitude and equal to 1000 $\mathrm{g} / \mathrm{cm}^{2}$. [140]

atmosphere (The)--The envelope of air surrounding the Earth and bound to it by the Earth's gravitationial attraction. Studies of the chemical properties, dynamic motions, and physical processes of this system constitute the field of meteorology. [9]

atmospheric turbulence-A state of the flow of air in which apparently random irregularities occur in the air's instantaneous velocities, often producing major deformations of the flow. $[100,127]$

atmospheric window-The spectral region between 8.5 and 11.0 microns where the atmosphere i: essentially transparent to longwave radiation. [105]

autotrophic-An organism that produces food from inorganic substances. [140]

baroclinic model-A model of atmospheric circulation that, in contrast with barotropic models, does not constrain constant-pressure surfaces to coincide with constant-density surfaces. [100]

basal sliding (basal slip)-The movement or speed of movement of a glacier on its bed. [102]

bathymetry-The science of measuring ocean depths to determine the topography of the sea floor. [ $1(\mathrm{~N})]$

benthic organism (benthos)-A form of aquatic plant or animal life that is found on or near the bottom of a stream, lake, or ocean. [140]

benthic region-The bottom layer of a body of water. [140]

biogeochemical cycle-The chemical interactions among the atmosphere, biosphere, hydrosphere, and lithosphere. [100]

biological productivity-The amount of organic matter, carbon, or energy content that is accumulated during a given time period. [100]

biumass - The total dry organic matter or stored energy content of living organisms that is present at a specific time in a defined unit (community, ecosystem, crop, etc.) of the Earth's surface. $[10,11]$

biosphere--The portion of Earth and its atmosphere that can support life. The part (reservoir) of the global carbon cycle that includes living organisms (plants and animals) and life-derived organic matter (litter, detritus). The terrestrial biosphere includes the liv- 
ing biota (plants and animals) and the litter and soil organic matter on land, and the marine biosphere includes the biota and detritus in the oceans. $[12,140]$

biota-The animal and plant (fauna and flora) life of a given area. $[100]$

bitumen-Dark, naturally oscurring solid or semisolid substances composed mainly of a mixture of hydrocarbons with little oxygen, nitrogen, or sulfur. [100]

buffer factor (Revelle factor)-The ratio of the instantaneous fractional change in the partial pressure of $\mathrm{CO}_{2}$ $\left(\mathrm{pCO}_{2}\right)$ exerted by seawater to the fractional change in total $\mathrm{CO}_{2}$ dissolved in the ocean waters. The buffer factor relates the partial pressure of $\mathrm{CO}_{2}$ in the ocean to the total ocean $\mathrm{CO}_{2}$ concentration at constant temperature, alkalinity and salinity. The Revelle factor is a useful parameter for examining the distribution of $\mathrm{CO}_{2}$ between the atmosphere and the ocean, and measures in part the amount of $\mathrm{CO}_{2}$ that can be dissolved in the mixed surface layer. [13-16]

C3 plants-Plants (e.g., soybean, wheat, and cotton) whose carbon-fixation products have three carbon atoms per molecule. Compared with $\mathrm{C} 4$ plants, $\mathrm{C} 3$ plants show a greater increase in photosynthesis with a doubling of $\mathrm{CO}_{2}$ concentration and less decrease in stomatal conductance, which results in an increase in leaf-level water-use efficiency. $[110,111]$

C4 plents-Plants (e.g., maize and sorghum) whose carbon fixation products have four carbon atoms per molecule. Compared with $\mathrm{C} 3$ plants, $\mathrm{C} 4$ plants show little photosynthetic response to increased $\mathrm{CO}_{2}$ concentrations above $340 \mathrm{ppm}$ but show a decrease in stomatal conductance, which results in an increase in photosynthetic water-use efficiency. $[110,111]$

alcrete-A surficial gravel and sand conglomerate cemented by calcium carbonate. [100]

caliche-Also called hardpan; an opaque, reddishbrown-to-white calcareous material, which occurs in layers near the surface of stony soils in arid and semiarid areas. [100]

Calvin cycle--The incorporation of $\mathrm{CO}_{2}$ into glucose $u$ enzy. matic reactions. [103]

CAM plants (crassulacean acid metabolism)--Plants (e.g, cactus and other succulents) that, unlike the $C 3$ and $\mathrm{C} 4$ plants, temporarily separate the processes of carbon dioxide uptake and fixation when grown 
under arid conditions. They take up gaseous carbon dioxide at night when the stomata are open and water loss is minimal. During the day when the stomata are closed, the stored $\mathrm{CO}_{2}$ is released and chemically processed. When CAM plants are not under water stress, they then follow $\mathrm{C} 3$ photosynthesis. [122]

canopy--.The branches and leaves of woody plants that are formed some distance above the ground. [116]

carbon-based resources--The recoverable fossil fuel (coal, gas, crude oils, oil shale, and tar sands) and biomass that can be used in fuel production and consumption. [23]

carbon budget -The balance of the exchanges (incomes and losses) of carbon between the carbon reservoirs or between one specific loop (e.g., atmosphere - biosphere) of the carbon cycle. All examination of the carbon budget of a pool or reservoir can provide information about whether the pool or reservoir is functioning as a source or sink for $\mathrm{CO}_{2},[17,18]$

carbon cycle All parts (reservoirs) and fluxes of carbon; usually thought of as a series of the four main reservoirs of carbon interconnected by pathways of exchange. The four reservoirs, regions of the Earth in which carbon behaves in a systematic manner, are the atmosphere, terrestrial biosphere (usually includes fresh water systems), oceans, and sediments (includes fossil fuels). Each of these global reservoirs maty be subdivided into smaller pools ranging in size from individual communities or ecosystems to the total of all living organisms (biota). Carbon exchanges from reservoir to reservoir by various chemical, physical, geological, and biological processes. $[19,20,21]$

carbon density . The amount of carbon per unit area for a given ecosystem or vegetation type, based on climalic conditions, tomerefally, vegetative-cover lype and amoum, arils, and maturity of the vegeta. tive standis. $\{22\}$

carbon dioxide fertilization Lnhancement of plant growth or of the net primasy presluction by $\mathrm{C}_{2} \mathrm{O}_{2}$ enrichment that could oecur in natural or agricultural systems as a result of an increase in the atmospheric concentration of $\mathrm{CO}_{2}$. [21]

carbon dioxide reference gas . A mixture of a known quantity of $\mathrm{CO}_{2}$-in-air or $\mathrm{CO}_{2}$-in- $\mathrm{N}_{2}$ used to calibrate carbon dioxide analyzers. [34]

carbon flux ...The rate of exchange of carbon between pools (reservoirs). [22] 
carbon isotope ratio-Ratio of carbon-12 to either of the other, less common, carbon isoiopes, carbon-13 or carbon-14. [190]

carbon poot-The rese.voir containing carbon as a principal element in the geochenical cycle. [22]

carbon sink-A pool (reservoir) that absorbs or takes up released carbon from another part of the carbon cycle. For example, if the net exchange between the biosphere and the atmosphere is toward the atmo sphere, the biosphere is the source, and the atmosphere is the sink. $[19,20]$

carbon source-A pool (reservoir) that releases carbon to another part of the carbon cycle. $[19,20]$

cutanedromous-Fish that swim downstream to spawn. [140]

Chernozern (Tchermozem)-A major group of dark-colored zonal soils with rich and deep humus horizon occurring in temperate-to-cool, subhumid clir rates. [100]

cinlorofuorocarbons-A family of inert nontoxic and easily liquified chemicals used in refrigeration, air conditionirg, packaging, and insulation or as solvents or aerosol propellants. Because they are not destroyed in the lower atmosphere, they drift intc the upper atmosphere where their chlorine components destroy ozone. [140]

chloroplast-An organelle in the cells of green plants. It contains chlorophyll and functions in photosynthesis and protein synthesis. [100]

clear cutting-A forest-management technique that involes harvesting all the trees in one area at one time. [140]

climate--The statistical collection and representation of the weather conditions for a specified area during a specified time interval, usually decades, together with a description of the state of the external sys. tem or boundary conditions. The properties that characterize the climate are thermal (temperatures of the surface air, water, land, and ice), kinetic (wind and ocean currents, together with associated vertical motions and the motions of air manses, aqueous humidity, cloudiness and cloud water content, groundwater, lake lands, and water content of snow on land and sea ice), and static (pressure and density of the atmosphere and ocean, composition of the dry air, salinity of the occans, and the geometric boundaries and physical constants of the system). These properties are interconnected by the various physical processes such as precipitation, 
evaporation, infrared radiation, convection, advection, and turbulence. $[25,26]$

climate chunge-The long-term fluctuations in temperature, precipitation, wind, and all other aspects of the Earth's climate. External processes, such as solarirradiance variations, variations of the Earth's orbil.al parameters (eccentricity, precession, and inclina(ion), lithosphere motions, and volcanic activity, are factors in climatic variation. Internal variations of the climate system also produce fluctuations of sufficient magnitude and variability to explain observed climate change through the feedback processes interrelating the components of the climate system. [24]

cllmate sensitivity--The magnitude of a climatic response to a perturbing influence. In mathematical modeling of the climate, the difference between simulations as a fulnction of change in a given parameter. [107]

climate sigmal- A statistically significant difference between the control and disturbed (sec climate sensitivity) simulations of a climate model. [107]

climate systein-The five physical components (atmosphere, hydrosphere, cryosphere, lithosphere, and biosphere) that are responsible for the climate and its variations. [25]

climate variation--The change in one or more climatic variables over a specified time. [26]

climatic analog-A past climate situation in which changes similar to the present occurred. Used in making climatic projections. [107]

climatic anomaly-- The deviation of a particular climatic variable from the mean or normal over a specified time. $[25,20]$

climatic optimum - The period in history from about 5000 to about 2500 B.C. during which surface air temperatures were warmer than at present in nearly all regions of the world. In the Arctic region, the temperature rose many degrees, and in temperate regions, the increase was $1.0^{\circ}-1.7^{\circ} \mathrm{C}$. In this period, glaciers and ice-sheets receded greatly, and the melt-water raised sea level by about 3 meters. $[27,28]$

cloud--A visible mass of condensed water vapor particles or ice suspended above the Earth's surface. Clouds may be classified on their visual appearance, height, or form. $[3,29]$ 
cloud albedo-Reflectivity that varies from less than 10 to more than $90 \%$ of the insolation and depends on drop sizes, liquid water content, water vapor content, thickness of the cloud, and the sun's zenith angle. The smaller the drops and the greater the liquid water content, the greater the cloud albedo, if all other factors are the same. [29]

cloud feedback - The coupling between cloudiness and surface air temperature in which a change in surface temperature could lead to a change in clouds, which could then amplify or diminish the initial temperature perturbation. For example, an increase in surface air temperature could increase the evaporation; this in turn might increase the extent of cloud cover. Increased cloud cover would reduce the solar radiation reaching the Earth's surface, thereby lowering the surface temperature. This is an exam. ple of negative feedback and does not include the effects of longwave radiation or the advection in the oceans and the atmosphere, which must also be considered in ine overall relationship of the climate system. $[30,31]$

constal zone-Lands and waters adjacent to the coast that exert an influence on the uses of the sea and its ecolngy or whose uses and ecology are affected by the sea. [140]

composting--The natural biological decomposition of organic material in the presence of air to form a humus-like material. [140]

continental crust--The layer of the Earth that lies under continents and the contiatental sheives. It ranges in thickness from 35 to $60 \mathrm{~km}$. Its upper layer has a density of $-2.7 \mathrm{~g} / \mathrm{cm}^{3}$ and is composed of rocks that are rich in silica and alumina. $[100,130]$

continental plate-A thick continental crust. [100]

continental sbelres--Those parts of the continent that are covered by water. They are several to more than $322 \mathrm{~km}$ wide and about $122 \mathrm{~m}$ deep. At the edges of the shelves, the continental slopes drop rapidly from 100 to $200 \mathrm{~m}$ to 3000 to $3700 \mathrm{~m}$. [101]

continental slopes-See continental shelves.

convection-Atmospheric or oceanic motions that are predominately vertical and that result in vertical transport and mixing of atmospheric or oceanic properties. Because the most striking meteorological features result if atmospheric convective motion occurs in conjunction with the rising current of air (i.e., updrafts), convection is sometimes used to imply only upward vertical motion. [32] 
convective adjustment-A numerical procedure applied in many atmospheric models to approximate the vertical nonradiative heat transport. This procedure adjusts the lapse rate whenever necessary so that some prescribed critical lapse rate is never exceeded. [32]

convergence-The quasi-horizontal flow of a fluid toward a common destination from different directions. When waters of different origins come together at a point or along a line (convergence line), the denser water from one side sinks under the lighter water from other side. The ocean convergence lines are the polar, subtropical, tropical, and equatorial. Also see divergence. [117]

Coriolis effect-The tendency for an object moving above the Earth to turn to the right in the Northern Hemisphere and to the left in the Southern Hemisphere relative to the Earth's surface. The effect arises because the Earth rotates and is not, therefore, an inertial reference frame. [100]

cotyledon-A leaf or leaves of the embryos of seed plants. They can function in food storage and can become photosynthetic wheil the seed germinates. [103]

crop water-use efmciency-A measure at the ecosystem level of how well plants use available water in growth. The grams of dry weight gained by plants during the growing season per unit land area are divided by the millimeters of water lost (including evaporation directly from the soil). [136, 137]

cryosphere-The portion of the climate system consisting of the world's ice masses and snow deposits, which includes the continental ice sheets, mountain glaciers, sea ice, surface snow cover, and lake and river ice. Changes in snow cover on the land surfaces are by and large seasonal and closely tied to the mechanics of atmospheric circulation. The glaciers and ice sheets are closely related to the global hydrologic cycle and to variations of sea level and change in volume and extent over periods ranging from hundreds to millions of years. [33]

decomposers-Heterotrophic organisms that break down dead protoplasm and use some of the products and release others for use by consumer organisms. [100]

decomposition-The breakdown of matter by bacteria and fungi. It changes the chemical makeup and physical appearance of materials. [140]

deep water-That part of the ocean below the main thermocline. [100] 
deforestation-The removal of forest stands by cutting and burning to provide land for agricultural purposes, residential or industrial building sites, roads, etc. or by harvesting the trees for building materials or fuel. Oxidation of organic matter releases $\mathrm{CO}_{2}$ to the atmosphere, and regional and global impacts may result. $[35,36]$

dendrochronology - The dating of past events and variations in the environment and the climate by studying the annual growth rings of trees. The approximate age of a temperate forest tree can be determined by counting the annual growth rings in the lower part of the trunk. The width of these annual rings is indicative of the climatic conditions during the period of growth; wide annual rings signify favorable growing conditions, absence of diseases and pests, and favorable climatic conditions, while narrow rings indicate unfavorable growing conditions or climate. $[39,40,41]$

dendroclimatology-The use of tree growth rings as proxy climate indicators. Tree rings record responses to a wider range of climatic variables over a larger part of the Earth than any other type of annually dated proxy record. $[37,38]$

desertification-The progressive destruction or degradation of vegetative cover especially in arid or semiarid regions bordering existing deserts. Overgrazing of rangelands, large-scale cutting of forests and woodlands, drought, and burning of extensive areas all serve to destroy or degrade the land cover. The climatic impacts of this destruction include increased albedo leading to decreased precipitation, which in turn leads to less vegetative cover; increased atmospheric dust loading could lead to decreased monsoon rainfall and greater wind erosion and/or atmospheric pollution. [42]

differentiation-The process by which single cells grow into particular forms of specialized tissue (e.g., root, stem, or leaf). [140]

divergence-A horizontal flow of water, in different directions, from a common center or zone; it is often associated with upwelling. Also see convergence. [117]

downwelling-The process of accumulation and sinking of warm surface waters along a coastline. A change of air flow of the atmosphere can result in the sinking or downwelling of warm surface water. The resulting reduced nutrient supply near the surface affects the ocean productivity and meteorological conditions of the coastal regions in the downwelling area. [43] 
dust reil index-A quantitative method developed by $H$. $H$. Lamb for comparing the magnitude of volcanic eruptions. The formulae use observations either of the depletion of the solar beam, temperature lowering in middle latitudes, or the quantity of solid matter dispersed as dust. The reference dust veil index is 1000 , assigned to the Krakatoa 1883 eruption, and the index is calculated using all three methods, where the information is available, for statistical amparison purposes. Abbreviated D.V.I. [44]

ecosystem-The interarting system of a biological community and its nonliving environmental surroundings. [140]

eddy-A circular movement of water or air that is formed where currents pass obstructions or between two adjacent currents that are flowing counter to each other. [67]

El Chicon-Active volcano $7300 \mathrm{ft}(2225 \mathrm{~m})$ high in Mexico. The last eruption was in 1983. [112]

El Nino-An irregular variation of ocean current that from January to March flows off the west coast of South America, carrying warm, low-salinity, nutrient-poor water to the south. It does not usually extend farther than a few degrees south of the equator, but occasionally it does penetrate beyond $12^{\circ} \mathrm{S}$, displacing the relatively cold Peru Current. The effects of this phenomenon are generally short-lived, and fishing is only slightly disrupted. Occasionally (in 1891, $1925,1941,1957-58,1965,1972-73,1976$, and 1982-83), the effects are major and prolonged. Under these conditions, sea surface temperatures rise along the coast of Peru and in the equatorial eastern Pacific Ocean and may remain high for more than a year, having disastrous effects on marine life and fishing. Excessive rainfall and flooding occur in the normally dry coastal area of western tropical South America during these events. Some oceanographers and metcorologists consider only the major, prolonged events as El Niño phenomena rather than the annually occurring weaker and short-lived ones. The name was originally applied to the latter events because of their occurrence at Christmas time. [45-48]

emissions-Materials (gases, particles, vapors, chemical compounds, etc.) that come out of smokestacks, chimneys, and tailpipes. [138]

emissivity-The ratio of the radiation emitted by a surface to that emitted by a black body at the same temperature. [100] 
energy balance models-An analytical technique to study the solar radiation incident on the Earth in which explicit calculations of atmospheric motions are omitted. In the zero-dimensional models, only the incoming and outgoing radiation is considered. The outgoing infrared radiation is a linear function of global mean surface air temperature, and the reflected solar radiation is dependent on the surface albedo. The albedo is a step function of the global mean surface air temperatures, and equilibrium temperatures are computed for a range of values of the solar constant. The one-dimensional models have surface air temperature as a function of latitude. At each latitude, a balance between incoming and outgoing radiation and horizontal transport of heat is computed. (Abbreviated as EBM.) [49]

environment-The sum of all external conditions affecting the life, development, and survival of an organism. [140]

epidemiology-The study of diseases as they affect populations, including the distribution of disease or other health-related states and events in human populations, the factors (e.g., age, sex, occupation, and economic status) that influence this distribution, and the application of this study to control health problems. [140]

equilibrium line-The level on a glacier where accumulation equals ablation and the net balance equals zero. [100]

estuary-Regions of interaction between rivers and near-shore ocean waters, where tidal action and river flow create a mixing of fresh and salt water. [140]

euphotic zone-The layer of a body of water that receives sufficient sunlight for photosynthesis. The depth of this layer, which is about $80 \mathrm{~m}$, is determined by the water's extinction coefficient, the cloudiness, and the sunlight's angle of incidence. [101]

evapotranspiration-Discharge of water from the Earth's surface to the atmosphere by evaporation from bodies of water, or other surfaces, and by transpiration from plants. [100]

feedback mechanisms--A sequence of interactions in which the final interaction influences the original one. Also see positive feedback and negative feedback. [50]

fen-A type of wetland that accumulates peat deposits; they are less acidic than bogs, deriving most of their water from groundwater rich in calcium and magnesium. [140] 
nro-Material that is transitional between snow and glacier ice. It is formed' from snow ufter passing through one summer meit season and becomes glacier ice after its permeability to liquid water falls to zero. [100]

first detection-Identification of a "precursor signal," deiectable above the "noise" of natural climatic variability, of a significant change in a climate parameter and attribution of this change to an increase in atmospheric carbon dioxide concentration. The signal may be estimated by numeric modeling of the climate, and the noise can be estimated using instrumental data. For any modeled signal that is estimated, the corresponding noise can be estimated from observational data, and a signal-to-noise ratio can be calculated to provide a quantitative measure of detectability. $[51,52,53]$

flaring - The burning of waste gases through a flare stack or other device before releasing them to the air. [138]

now law-In glaciology, a constitutive relation for the analysis of three-dimensional deformation states of ice subjected to stress. $[124,125]$

fog-Liquid particles less than 40 microns in diameter that are formed by condensation of vapor in air. [140]

food chuin-A sequence of organisms, each of which uses the next lower member of the sequence as a food source. [140]

fossil fuel-Any hydrocarbon deposit that can be burned for heat or power, such as petroleum, coal, and natural gas. [100]

fungi--Molds, mildews, yeasts, mushrooms, and puffballs, a group of organisms that lack chlorophyll and therefore are not photosynthetic. They are usually nonmobile, filamentous, and multicellular. [140]

general circulation models--Hydrodynamic models of the atmosphere on a grid or spectral resolution that determine the surface pressure and the vertical distributions of velocity, temperature, density, and water vapor as functions of time from the mass conservation and hydrostatic laws, the first law of thermodynamics, Newton's second law of motion, the equation of state, and the conservation law for water vapor. Abbreviated as GCM. Atmospheric general circulation models are abbreviated AGCM, while oceanic general circulation models are abbreviated OGCM. [54]

geomorphology - The study of present-day landforms, including their classification, description, nature, origin, 
development, and relationships to underlying structures. Also the history of geologic changes as recorded by these surface features. The term is sometimes restricted to features produced only by erosion and deposition. [102]

geosphere-The solid mass (lithosphere) of the Earth as distinct from the atmosphere and hydrosphere or all three of these layers combined. [100]

geostrophic flow-A type of movement where the Coriolis force balances exactly the horizontal pressure force. [100]

glacial maximum-The position or time of the greatest advance of a glacier (e.g., the greatest equatorward advance of Pleistocene glaciation). [100]

glacial rebound-The isostatic adjustment of previously glaciated areas after glacial retreat (e.g., the uplift of Scandinavia after the most recent glaciation). [114]

glacier-A mass of land ice that is formed by the cumulative recrystallization of firn. A glacier flows slowly (at present or in the past) from an accumulation area to an ablation area. Some well-known glaciers are: the Zermatt, Stechelberg, Grindelwald, Trient, Les Diablerets, and Rhone in Switzerland; the Nigards, Gaupne, Fanarak, Lom, and Bover in Norway; the Wright, Taylor, and Wilson Piedmont glaciers in Antarctica; the Bossons Glacier in France; the Emmons and Nisqually glaciers on Mt. Ranier, Washington; Grinnell glacier in Glacier National Park, Montana; the Dinwoody glacier in the Wind River Mountains and the Teton glacier in Teton National Park, both in Wyoming; and many glaciers in the Canadian Rockies. $[100,101]$

glacier flow (ice now)-The slow downward or outward movement of ice in a glacier caused by gravity. [102]

greenhouse effect-A popular term used to describe the roles of water vapor, carbon dioxide, and other trace gases in keeping the Earth's surface warmer than it would be otherwise. These "radiatively active" gases are relatively transparent to incoming shortwave radiation, but are relatively opaque to outgoing longwave radiation. The latter radiation, which would otherwise escape to space, is trapped by these gases within the lower levels of the atmosphere. The subsequent reradiation of some of the energy back to the surface maintains surface temperatures higher than they would be if the gases were absent. There is concern that increasing concentrations of greenhouse gases, including carbon dioxide, 
wethane, and manmade chlorofluorocarbons, may enhance the greenhouse effect and cause global warming. [55]

greenhouse gases-Those gases, such as water vapor, carbon dioxide, tropospheric ozone, nitrous oxide, and methane, that are transparent to solar radiation but opaque to longwave radiation. Their action is similar to that of glass in a greenhouse. Als see greenhouse effect and trace gas. [105]

\section{Greenland Ice Sheet-See ice sheet}

grenz-A soil horizon, which is frequently marked by a bed of clay, that results from a temporary halt in the accumulation of vegetal material. [118]

gross primary production-The total amount or weight of organic matter created by photosynthesis over a defined time period (total product of photosynthesis). Abbreviated GPP. [56]

ground cover-Plants grown to keep soil from eroding. [140]

grounding line-The boundary between the area where an ice shelf or a glacier is floating on water and where it is in contact with the shore or underlying earth ("grounded"). [125]

groundwater-The supply of fresh water found beneath the surface of the Earth (usually in aquifers) that often supplies wells and springs. [140]

growth water-use efficiency-A measure at the individual plant level of how well plants use available water in growth. The units of dry matter synthesized are divided by the units of water lost. [136, 137]

Gulf Stream meander-A transient winding bend in the Gulf Stream. These bends intensify as the Gulf Stream merges into the North Atlantic and can break up into detached eddies at about $40^{\circ} \mathrm{N} .[100]$

gyres-Major circular flow patterns in the oceans. The winddriven eastward- and westward-flowing equatorial currents are blocked by the continents and rotate slowly in a clockwise direction in the North Atlantic and Pacific Oceans and in a counter-clockwise direction in the South Atlantic, South Pacific, and Indian Oceans. $[57,58]$

Hadley cell-A direct thermally-driven and zonally symmetric large-scale atmospheric circulation first proposed by George Hadley in 1735 as an explanation for the trade winds. It carries momentum, sensible heat, and potential heat from the tropics to the midlatitudes $\left(30^{\circ}\right)$. The poleward transport aloft is complemented by subsidence in the subtropical high 
pressure ridge and a surface return flow. The variability of this cell and the Walker cell is hypothesized to be a major factor in short-term climatic change. $[65,75]$

halocline-In the oceans, a well-defined vertical gradient of salinity. [100]

heat flux (thermal nux)-The amount of heat that is transferred across a surface of unit area in a unit of time. [100]

heat island effect-A "dome" of elevated temperatures over an urban area caused by the heat absorbed by structures and pavement. [140]

herbivore-An animal that feeds on plants. [140]

heterotrophs - Organisms that break down and use organic matter. [100]

histosol--Wet organic soils, such as peats and mucks. [100]

Holdridge life zone-A climate category defined by three weighted climatic indexes, namely, mean annual heat, precipitation, and atmospheric moisture. [94]

Holocene-The most recent epoch of the Quaternary period, covering approximately the last 10,000 years. [28]

humus-Decomposed organic material. [140]

hydrologic budget - A quantitative accounting of all water volumes and their changes with time for a basin or area. [120]

hydrologic cycle-The process of evaporation, vertical and horizontal transport of vapor, condensation, precipitation, and the flow of water from centinents to oceans. It is a major factor in determining climate through its influence on surface vegetation, the clouds, snow and ice, and soil moisture. The hydrologic cycle is responsible for 25 to 30 percent of the mid-latitudes' heat transport from the equatorial to polar regions. [59]

hydrology-The science dealing with the properties, distribution, and circulation of water. [140]

liydrosphere-The aqueous envelope of the Earth, including the oceans, freshwater lakes, rivers, saline lakes and inland seas, soil moisture and vadose water, groundwaters, and atmospheric vapor. [60]

hydrostatic equation-In the vector equation of motion, the form assumed by the vertical component when all 
Coriolis, earth-curvature, frictional, and verticalasceleration terms are considered negligible compared with those involving the vertical pressure force and the force of gravity. The error in applying the hydrostatic equation to the atmosphere for cyclonic-scale motions is less than $0.01 \%$. In extreme situations, the strong vertical accelerations in thunderstorms and mountain waves can he $1 \%$ of gravity. [3]

hypsithermal perind-The period about 4000 to 8000 years ago when the Earth was apparently several ciegrees warmer than it is now. More rainfall occurred in most of the subtropical desert regions and less in the central midwest United States and Scandinavia. It is also called the "altithermal period" and can serve as a past climate analog for predicting the regional pattern of climate change should the mean Earth surface temperature increase from an increase in atmospheric carbon dioxide concentration. $[27,28]$

Ice age-A glacial epoch or time of extensive glacial activity. Also, as Ice Age, which refers to the latest glacial epoch, the Pleistocene Epoch. [102]

ice and snow albedo-The reflectivity of ice and snow-covered surfaces. The albedo of freshly fallen snow may be as much as $90 \%$, while older snow may have values of $75 \%$ or less. The larger the areal extent of snow and ice cover, the higher the albedo value. The surface albedo will also increase as a function of the depth of snow cover up to $13 \mathrm{~cm}$ and be inaffected by increased snow cover after reaching that depth. $[5,61]$

ice and snow-albedo-temperature feedback-Interactions that can be described as a theoretical concept of a feedback mechanism in which the interacting elements are the areal extent of polar ice ar 1 snow cover, the albedo of the polar region (dependent on areal extent of ice and snow), absorption of solar radiation (dependent on the albedo), temperature (dependent on the absorption of solar radiation) and the area of ice and snow cover (dependent on temperature). Less snowfall would mean more absorption of solar radiation, therefore a surface warming would occur. Climate modeling studies indicate an amplification effect (i.e., positive feedback) of the ice and snow-albedo feedback on increased surface air temperatures caused by increases in the atmospheric concentration of carbon dioxide. [50]

Ice cover-During the present time, the extent, especially the thickness, of glacier ice on a land surface. Also the 
same as ice concentration, which is the ratio of an area of sea ice to the total area of sea surface within some large geographic area. [102]

ice flow-See glacier flow.

ice front-The floating vertical cliff that forms the seaward face or edge of a glacier or an ice shelf that enters water. It can vary from 2 to $50 \mathrm{~m}$ in height. [102]

ice sheet (continental glacier)-A glacier of considerable thickness and more than $50,000 \mathrm{sq} \mathrm{km}$ in area. It forms a continuous cover of ice and snow over a land surface. An ice sheet $i$. not confined by the underlying topography but spreads outward in all directions. During the Pleistocene Epoch, ice sheets covered large parts of North America and northern Europe but they are now confined to polar regions (e.g., Greenland and Antarctica). [102]

ice shelf-A sheet of very thick ice with a level or gently undulating surface. It is attached to the land on one side, but most of it is floatıng. On the seaward side, it is bounded by a steep cliff (ice front) 2 to $50 \mathrm{~m}$ or more above sea level. Ice shelves have formed along polar coasts (e.g., Antarctica and Greenland); they are very wide with some extending several hundreds of kilometers loward the sea from the coastline. They increase in size from annual snow accumulation and seaward extension of land glaciers. They decrease in size from warming, melting, and calving. [102]

incident solar flux-See solar irradiance

infiltration (soil)--Movement of water from the ground surface into the soil. [100]

infrared radiation-Electromagnetic radiation lying in the wavelength interval from $0.7 \mu \mathrm{m}$ to $1000 \mu \mathrm{m}$. Its lower limit is bounded by visible radiation, and its upper limit by microwave radiation. Most of the energy emitted by the Earth and its atmosphere is at infrared wavelength. Infrared radiation is generated almost entirely by large-scale intramolecular processes. The tri-atomic gases, such as water vapor, carbon dioxide, and ozone, absorb infrared radiation and play important roles in the propagation of infrared radiation in the atmosphere. Abbreviated IR; also called "longwave radiation." $[3,62]$

insolation-The solar radiation incident on a unit horizontal surface at the top of the atmosphere. It is sometimes referred to as solar irradiance. The latitudinal variation of insolation supplies the energy for the general circulation of the atmosphere. Insolation 
depends on the angle of incidence of the solar beam and on ihe solar constant. [62]

instantaneous transpiration efficiency-A measure at the physiologic level of how well plants use available water in photosynthesis. The assimilation rate is divided by the transpiration rate; the moles of $\mathrm{CO}_{2}$ taken up are divided by the moles of water lost through transpiration in a unit of time. $[136,137]$

inversion--An anomaly in the normal positive lapse rate; usually refers to a thermal inversion, in which temperature increases rather than decreases with height. [141]

irrediance- The total radiant flux received on a unit area of a given real or imaginary surface. Also called the radiant flux density. [119, 127]

isopynic--A line on a chart that connects all points of equal or constant density. [100]

isostatic adjustment (isostatic ccmpensation)-.The process whereby lateral transport at the Earth's surface from erosion or deposition is compensated for by movements in a subcrustal layer to maintain equilibrium among units of varying masses and densities. $[100,130]$

isotherm-A line on a chart that connects all points of equal or constant temperature. [100]

isotope-One of two or more atoms that have the same atomic number (i.e., the same number of protons in their nuclei) but have different mass numbers. [100]

Krakatoa (Krakatau)-Active volcano $2667 \mathrm{ft}(813 \mathrm{~m})$ high in West indonesia. It forms an island between Java and Sumatra. Its eruption in 1883, which was one of the most violent in modern times, scattered debris and darkened skies over vast areas. Additional eruptions occurred in late 1927 and in the 1960s. [113]

lapse rate-The rapidity with which temperature decreases with altitude. The normal lapse rate is defined to be $3.6^{\circ} \mathrm{F}$ per 1000 feet change in altitude. The dry adiabatic lapse rate is about $5.5^{\circ} \mathrm{F}$ per 1000 feet, and the wet adiabatic lapse rate varies between 2 and $5^{\circ} \mathrm{F}$ per 1000 feet. $[64,65]$

latent heat-Energy transferred from the earth's surface to the atmosphere through the evaporation and condensation processes. [63] 
Le Chatelier's principle - When an external force is applied to an equilibrium system, the system adjusts to minimize the effect of the force. [100]

IIfe zone-A climatically-defined class that can be associated with regions of soil and biota with a high uniformity in species composition and environmental adaptation. See Holdridge llfe zone. [94]

Uthosphere-The component of the Earth's surface comprising the rock, soil, and sediments. It is a relatively passive component of the climate system, and its physical characteristics are treated as fixed elements in the determination of climate. $[60]$

IItter-Undecomposed plant residues on the soil surface. [116]

Little Ice Age-A cold period that lasted from about A.D. 1550 to about A.D. 1850 in Europe, North America, and Asia. This period was marked by rapid expansion of mountain glaciers, especially in the Alps, Norway, Ireland, and Alaska. There were three maxima, beginning about 1650 , about 1770 , and 1850 , each separated by slight warming intervals. $\{27,28\}$

loess-A buff-colored, wind-blown deposit of fine silt, which is frequently exposed in bluffs with steep faces. The thickness can range from 6 to $30 \mathrm{~m}$. The loess of the USA and Europe is thought to be the fine materials first transported and deposited by the waters of melting ice sheets during the glacial period. It was later blown considerable distances with, in some cases, deposition in lakes. The origin of Asiatic loess, however, is apparently wind-blown dust from central Asian deserts. [101]

longware radiation--The radiation emitted in the spectral wavelength greater than $4 \mu \mathrm{m}$ corresponding to the radiation emitted from the Earth and atmosphere. It is sometimes referred to as "terrestrial radiation" or "infrared radiation," although somewhat imprecisely. [62]

marsh- A type of wetlead that does not accumulate appreciable peat deposits and is dominated by herbacious vegetation. Marshes may be fresh- or saltwater, tidal or nontidal. [140]

muss balance- The appication of the principle of the conservation of matter. For example, the mass of a glacler is not destroyed or created; the mass of a glacier and all its constitutive componerits remains the same despite alterations in their physical states. The mass balance of a glacier is calculated with the 
input/output relationships of ice, firn, and snow, usually measured in water equivalent. Output includes all ablative processes of surface melting, basal melting, evaporation, wind deflation, salving, and internal melting. Input includes direct precipitation, avalanching, and the growth of superim. posed ice. $[124,125]$

Maunn Lon-An intermittently active volcano $13,680 \mathrm{ft}$ $(4,170 \mathrm{~m})$ high in Hawaii. Last eruption was in 1984. Also see Mauna Lon record. [113]

Mauna Loa record-The record of measurements of atmospheric carbon dioxide concentrations taken at the Mauna Loa Observatory, Mauna Loa, Hawaii, since March 1958. The Mauna Loa record is the longest reliable daily record of atmospheric carbon dioxide measurements in the world. [66]

Maunder minimum - The period from 1654 to 1714 when it was believed that there were no sunspots. It is now thought that there were some sunspots during that time but less than the numbers counted after 1800 . [115]

mean sea level--The average height of the sea surface, based upon hourly observation of the tide height on the open coast or in adjacent waters that have free access to the sea. In the United States, it is defined as the average height of the sea surface for all stages of the tide over a nineteen year period. Mean sea level, commonly abbreviated as MSL and referred to simply as "sea level," serves as the reference surface for all altitudes in upper atmospheric studies. [67]

mesic environment-A habitat with a moderate amount of water. [100]

mesoscale eddies (mode eddies)-In the ocean, dense and irregularly-oval high- and low-pressure centers about $400 \mathrm{~km}$ in diameter. The intensities of currents in these centers are about 10 times greater than the local means. [100]

Milankovitch theory-An astronomical theory formulater by the Yugoslav mathematician Milutin Milankovitch that associates climate change with fluctuations in the seasonal and geographic distribution of insolation determined by periodic variations of the Earth's eccentricity and obliquity and the longitude of the perihelion. $[55,69,130]$

mist-Liquid particles 40 to 500 microns in diameter that are formed by condensation of rapor in air. [14n] 
modeling-An investigative technique that uses a mathematical or physical representation of a system or theory that accounts for all or some of its known properties. Models are often used to test the effects of changes of system components on the overall performance of the system. [140]

monsoon-A name for seasonal winds, first applied to the winds over the Arabian Sea that blow for six months from the northeast and for six months from the southwest. The term has been extended to similar winds in other parts of the world (i.e., the prevailing west to northwest winds of summer in Europe have been called the "European monsoon" ${ }^{n}$ ). The primary cause for these seasonal winds is the much greater annual variation of temperature over large land arc.s compared with neighboring ocean surfaces, causing an excess of pressure over the continents in winter and a deficit in summer, but other factors, such as topography of the land, also have an effect. The monsoons are strongest in the southern and eastern sides of Asia, but also occur along the coasts of tropical regions wherever the planetary circulation is not strong enough to inhibit them. The monsoon climate can be described as a long winter-spring "dry season," which includes a "cold season" followed by a short "hot season" just preceding the rains; a summer and early autumn rainy season, which is generally very wet but may vary greatly from year to year; and a secondary warming immediately after the rainy season. [3]

natural selection--The process of survival of the fittest by which organisms that adapt to their environment survive while those that do not adapt disappear. [140]

negative feedback-An interaction that reduces or dampens the response of the system in which it is incorporated. [50]

net primary production-The part of the gross primary production that remains stored in the producer organism (primarily green plants) after deducting the amount used during the process of respiration. Abbreviated NPP. [56]

nutrient--Any substance assimilated by living things that promotes growth. [140]

ocenn mixing--Processes that involve rates of advection, upwelling/downwelling, and eddy diffusion and that determine how rapidly excess atmospheric carbon dioxide can be taken up by the oceans. $[69,70]$

opacity - The degree of obscuration of light; for example, a glass window has almost 0\% opacity, whereas a concrete wall has $100 \%$ opacity. [139] 
optical thickness (optical depth)-In calculating the transfer of radiant energy, the mass of an absorbing or emitting material lying in a vertical column of unit cross-sectional area and extending between two specified levels. Also, the degree to which a clous prevents light from passing through it; the optical thickness then depends on the physical constitution (crystals, drops, and/or droplets), the form, the concentration, and the vertical extent of the cloud. $[100,127]$

ozone-A molecule made up of three atoms of oxygen. In the statosphere, it occurs naturally and it provides a protective layer shielding the Earth from ultraviolet radiation and subsequent harmful health effects on humans and the environment. In the troposphere, it is a chemical oxidant and major component of photochemical smog. [140]

paleosol-An ancient soil or soil horizon that formed on the surface during the geologic past. [100]

paludification- The expansion of a bog caused by the gradual rising of the water table as accumulation of peat impedes water drainage. [100]

palynology - The science of reconstructing the past flora and past climate from pollen data obtained from lake and bog sediments. The fossil pollen record is a function of the regional flora and vegetation at a given time and location. [68]

particulate matter--Very small pieces of solid or liquid matter, such as particles of soot, dust, aerosols, fumes, or mists. [139]

past climate analogs--The reconstructing of past climates at a given locality from modern climatic conditions in a different elevation or latitudinal zone to infer past climatic conditions. [68]

$\mathrm{pCO}_{2}-$ The partial pressure of $\mathrm{CO}_{2}$ in the atmosphere and the ocean. In the atmosphere, the partial pressure of $\mathrm{CO}_{2}$ is defined as the pressure the $\mathrm{CO}_{2}$ would exert if all other gases were removed. The sum of the partial pressure of all the atmospheric gases will equal the atmospheric pressure. The partial pressure of $\mathrm{CO}_{2}$ in the atmosphere is determined by the atmospheric $\mathrm{CO}_{2}$ concentration and atmospheric temperature. In the ocean, the $\mathrm{pCO}_{2}$ is determined by the amount of dissolved $\mathrm{CO}_{2}$ and $\mathrm{H}_{2} \mathrm{CO}_{3}$. It varies with alkalinity, latitude, depth, and temperature. Biological processes in the ocean also exert an influence on the $\mathrm{pCO}_{2}$ in the ocean. $[70,71]$

percolation - The movement of water downward and radially thirough the subsurface soil layers, usually continuing downward to the groundwater. [140] 
permafrost-Perennially frozen ground that occurs wherever the temperature remains below $0^{\circ} \mathrm{C}$ for several years. [100]

phenology - The study of periodic biological phenomena with relation to climate, particularly seasonal changes. These phenomena can be used to interpret local seasons and the climatic zones. [100]

photochemical smog-Air pollution caused by chemical reactions among various substances and pollutants in the atmosphere. [140]

photosynthesis-The manufacture by plants of carbohydrates and oxygen from carbon dioxide and water in the presence of chlorophyll with sunlight as the energy source. Oxygen and water vapor are released in the process. Photosynthesis is dependent on favorable temperature and moisture conditions as well as on the atmospheric carbon dioxide concentration. Increased levels of carbon dioxide can increase net photosynthesis in many plants. $[72,73,140]$

phytoplankton-That portion of the plankton community comprised of tiny plants (e.g., algae and diatoms). [140]

planetary albedo-The fraction (approximately 30\%) of incident solar radiation that is reflected by the earth-atmosphere system and returned to space, mostly by backscatter from clouds in the atmosphere. [5]

planetary boundary layer--The transition region between the turbulent surface layer and the normally nonturbulent free atmosphere. This region is about! $\mathrm{km}$ in thickness and is characterized by a welldevcloped mixing generated by frictional drag as the air masses move over the Earth's surface. This layer contains approximately $10 \%$ of the mass of the atmosphere. Also called the "atmospheric boundary layer" or "frictional layer." [74]

plankton-Passively floating or weakly motile aquatic plants (phytoplankton) and animals (zooplankton). [100]

Pleistocene-The earlier of the two epochs of the Quaternary period, starting 2 to 3 million years before the present and ending about 10,000 years ago. It was a time of glacial activity. [130]

positive feedback---An interaction that amplifies the response of the system in which it is incorporated. [50]

precipitation-Any or all forms of liquid or solid water particles that fall from the atmosphere and reach the Earth's surface. It includes drizzle, rain, snow, snow pellets, snow grains, ice crystals, ice pellets, and 
hail. The ratio of precipitation to evaporation is the most important factor in the distribution of vegetation zones. Precipitation is also defined as a measure of the quantity, expressed in centimeters or milliliters of liquid water depth, of the water substance that has fallen at a given location in a specified amount of time. $[75,76]$

primary productivity - See gross primary production and net primary production.

primary succession-The natural development of vegetation and soil on a site that had not previously borne vegetation (e.g., a sand dune or lava flow), which vegetation will be replaced by other, successive plant communities. $[100,131]$

primitive equations-The Eulerian equations of fluid motion in which the primary dependent variables are the velocity components of the fluid. In meteorology, they can be specialized to apply directly to the cylonicscale motions. [100]

proxy climate indicators-Dateable evidence of a biological or geological phenomenon whose condition, at least in part, is attributable to climatic conditions at the time of its formation. Proxy data are any material that provides an indirect measure of climate and include documentary evidence of crop yields, harvest dates, glacier movements, tree rings, varves, glaciers and snow lines, insect remains, pollen remains, marine microfauna, isotope measurements: ${ }^{18} \mathrm{O}$, in ice sheets, ${ }^{18} \mathrm{O},{ }^{2} \mathrm{H}$, and ${ }^{13} \mathrm{C}$ in tree rings; $\mathrm{CaCO}_{3}$ in sediments; and speleothems. There are three main problems in using proxy data: (1) dating, (2) lag and response time, and (3) meteorological interpretation. Tree rings, pollen deposits from varved lakes, and ice cores are the most promising proxy data sources for reconstructing the climate of the last five millennia because the dating are precise on an annual basis while other proxy data sources may only be precise to \pm 100 years. [78]

pycnocline-In the ocean, a region where the water density increases rapidly with depth. [100]

pyrgeometer-An instrument that measures radiation from the earth's surface into space. [100]

Quaternary period-The latest period of geologic time, covering the most-recent 2,000,000 years of the Earth's history. It is divided into two epochs: the Pleistocene-2 million years ago to approximately 10,000 years ago-and the Holocene-the period from approximately 10,000 years ago to the present. The Quaternary period is the artificial division of time separating prehuman and human periods. It contains five ice ages and four interglacial ages, and 
temperature indicators seem to show sharp and abrupt changes by several degrees. $[28,127,130]$

radiant flux density - The total flow of radiation received on a unit area of a given real or imaginary surface. Also called the irradiance. $[119,127]$

radiation balance-The difference between the absorbed solar radiation and the net infrared radiation. Experimental data show that radiation from the earth's natural surfaces is rather close to the radiation from a black body at the corresponding temperature; the ratio of the observed values of radiation to black body radiation is generally $0.90-1,0$. [62]

radiative-convective models-Thermodynamic models that determine the equilibrium temperature distribution for an atmospheric column and the underlying surface, subject to prescribed solar radiation at the top of the atmosphere and prescribed atmospheric composition and surface albedo. Submodels for the transfer of solar and terrestrial radiation, the heat exchange between the earth's surface and atmosphere, the vertical redistribution of heat within the atmosphere, the atmospheric water vapor content and cloids are included in these one-dimensional models. Abbreviated as RCM. [54]

radiatively active gases-Gases that absorb incoming solar radiation or outgoing infrared radiatiou, thus affecting the vertical temperature profile of the atmosphere. Most frequently being cited as being radiatively active gases are water vapor, $\mathrm{CO}_{2}$, methane, nitrous oxide, chlorofluorocarbons, and ozone. [132, $133,134]$

radiosonde- $A$ balloon-borne instrument for the simultaneous measurement and transmission of meteorological data up to a height of approximately 30,000 meters $(100,000$ feet $)$. The height of each pressure level of the observation is computed from data received via radio signals. [3]

recharge-... The process by which water is added to a reservoir or zone of saturation, often by runoff or percolation from the soil surface. [140]

reflectivity-. The ratio of the energy carried by a wave that is reflected from a surface to the energy of a wave incident on the surface. [100]

relative sea level-w. The height of the boundary between sea and air as measured in relationship to a fixed reference point on land. [126]

reservoir-Any natural or artificial holding area used to store, regulate, or control a substance. [140] 
residence time--The size of any specific reservoir or pool of mass (e.g., carbon) divided by the total flux of mass into or out of that poo!. [79]

respiration-A biochemical process by which living organisms take up oxygen from the environment and consume organic matter, releasing both carbon dioxide and heat. In plants, the organic matter in photosynthate produced during daylight hours. [80]

Revelle factor-The ratio of the instantaneous fractional change in the partial pressure of $\mathrm{CO}_{2}\left(\mathrm{pCO}_{2}\right)$ exerted by seawater to the fractional change in total $\mathrm{CO}_{2}$ dissolved in the ocean waters. The buffer factor relates the partial pressure of $\mathrm{CO}_{2}$ in the ocean to the total ocean $\mathrm{CO}_{2}$ concentration at constant temperature, alkalinity and salinity. The Revelle factor is a useful parameter for examining the distribution of $\mathrm{CO}_{2}$ between the atmosphere and the ocean, and measures in part the amount of $\mathrm{CO}_{2}$ that can be dissolved in the mixed surface layer. [13-16]

rocketsonde- $A$ rocket-borne instrument for measurement and transmission of upper-air meteorological data in the lower 76,000 meters $(250,000$ feet $)$ of the atmosphere, especially that portion inaccessible to radiosonde techniques. [3]

runoff-That part of precipitation, snowmelt, or irrigation water that flnws from the land to streams or other surface waters. [140]

salinity--.-The degree of salt in water. [140]

salt water intrusion-The invasion of fresh, surface, or groundwater by salt water. [140]

seasonal variation-The change in a set of meteorological parameters averaged over three months. Seasonal variation is the largest climatic variation, and temperature is the most frequently observed meteorological parameter. Often, monthly averaged data are grouped into seasons, according to the prescribed definition. [26]

sea surface temperature- The temperature of the layer of seawater (approximately $0.5 \mathrm{~m}$ deep) nearest the atmosphere. [81]

secular carbon dioxide trend-The fairly uniform and accelerating increase of carbon dioxide concentration in the atmosphere, as illustrated by the Mauna Lon record. The secular trend reflects the increase in global atmospheric carbon dioxide concentrations produced by combustion of fossil fuels, kilning of limestone, and possibly a net biospheric release of carbon dioxide resulting from deforestation. [82] 
sensible beat-The excess radiative energy that has passed from the Earth's surface to the atmosphere through advection, conduction, and convection processes. [63]

shortwave radiation-The radiation received from the sun and emitted in the spectral wavelengths less than $4 \mu \mathrm{m}$. It is also called "solar radiation." [62]

signal-to-noise ratio-A quantitative measure of the statistical detectability of a signal, expressed as a ratio of the magnitude of the signal relative to the variability. For first detection of a $\mathrm{CO}_{2}$-induced climate change, the model signal is the mean change or anomaly in some climatic variable, usually surface air temperature, attributed by a numerical model to increased concentrations of carbon dioxide. Observed noise is the standard deviation or natural variability computed from observations of that variable and adjusted for sample size, autocorrelation, and time averaging. $[51,52,53]$

silviculture-Management of forest land for timber. [140]

smog-Air pollution associated vith oxidants. [140]

smoke-Particles suspended in air after incomplete combustion of materials. [140]

soll carbon-A major component of the terrestrial biosphere pool in the carbon cycle. Organic soil carbon estimates, rather than total soil carbon, are generally quoted. The amount of carbon in the soil is a function of historical vegetative cover and productivity, which in turn is dependent upon climatic variables. $[83,84]$

solar constant--The rate at which solar energy is received just outside the Earth's atmosphere on a surface that is normal to the incident radiation and at the mean distance of the Earth from the sun. The current value is $0.140 \mathrm{watt} / \mathrm{cm}^{2} .[100]$

solar cycle-The periodic change in sunspot numbers. It is the interval between successive minima and is about 11.1 years. [100]

Southern Oscillation--A large-scale atmospheric and hydrospheric fluctuation centered in the equatorial Pacific Ocean. It exhibits a nearly annual pressure anomaly, alternatively high over the Indian Ocean and high over the South Pacific. Its period is slightly variable, averaging 2.33 years. The variation in pressure is accompanied by variations in wind strengths, ocean currents, sea-surface temperatures, and precipitation in the surrounding areas. El Nino occurrences are associated with the phenomenon. [85-88, 129] 
Southern Oscillation Index-An indicator based on the pressure gradient between the quasi-stationary low pressure region and the center of a subtropical high pressure cell. A positive index corresponds to an anomalously high pressure difference between the two centers of action. [85-88, 129]

statistical-dynamical models-Computer programs that calculate simplified climate models based on versions of the conservation equations that have been averaged over longitude, with the effects of the synoptic eddies parameterized statistically in the meridional plane. $[54,135]$

steric height--The mean dynamic depth (or height) of the ocean for the month minus the annual mean dynamic depth for the same isobaric reference level. $[124,126]$

stoma, pl. stomata - A minute pore in the epidermis of plant leaves or stems. Stoma, which are bordered by guard cells that regulate the size of the opening, function in gas exchange between the plant and the external environment. The stomatal apparatus or stomate consists of the stoma plus guard cells. [103]

stratification-Separating into layers. [140]

stratosphere-The region of the upper atmosphere extending from the tropopause ( 8 to $15 \mathrm{~km}$ altitude) to about $50 \mathrm{~km}$. The thermal structure is determined by its radiation balance and is generally very stable with low humidity. [9]

Suess effect-The relative change in the ${ }^{14} \mathrm{C} / \mathrm{C}$ or ${ }^{13} \mathrm{C} / \mathrm{C}$ ratio of any carbon pool or reservoir caused by the addition of fossil-fuel $\mathrm{CO}_{2}$ to the atmosphere. Fossil fuels are devoid of ${ }^{14} \mathrm{C}$ because of the radioactive decay of ${ }^{14} \mathrm{C}$ to ${ }^{14} \mathrm{~N}$ during long underground storage and are depleted in ${ }^{13} \mathrm{C}$ because of isotopic fractionation eons ago during photosynthesis by the plants that were the precursors of the fossil fuels. Carbon dioxide produced by the combustion of fossil fuels is thus virtually free of ${ }^{14} \mathrm{C}$ and depleted in ${ }^{13} \mathrm{C}$. The term "Suess effect" originally referred to the dilution of the ${ }^{14} \mathrm{C} / \mathrm{C}$ ratio in atmospheric $\mathrm{CO}_{2}$ by the admixture of fossil-fuel produced $\mathrm{CO}_{2}$, but the definition has been extended to both the ${ }^{14} \mathrm{C}$ and ${ }^{13} \mathrm{C}$ ratios in any pool or reservoir of the carbon cycle resulting from human disturbances. [89]

sunspot-A relatively dark, sharply defined region on the solar disk, marked by an umbra approximately $2000 \mathrm{~K}$ cooler than the effective photospheric temperature, surrounded by a less dark but also sharply bounded penumbra. The average spot diameter is about $3700 \mathrm{~km}$, but can range up to 
$245,000 \mathrm{~km}$. Most sunspots are found in groups of two or more, but they can occur singly. Sunspots are cyclic, with a period of approximately 11 years. The quantitative description of sunspot activity is called the Wolf sunspot number, denoted $R$. The Wolf sunspot number is also referred to as "Wolfer sunspot number," "Zurich relative sunspot number," or "relative sunspot number, ${ }^{n}[90,91]$

surface air temperature--The temperature of the air near the surface of the Earth, usually determined by a thermometer in an instrument shelter about $2 \mathrm{~m}$ above the ground. The true daily mean, obtained from a thermograph, is approximated by the mean of 24 hourly readings and may differ by $1.0^{\circ} \mathrm{C}$ from the average based on minimum and maximum readings. The global average surface air temperature is $15^{\circ} \mathrm{C}$ $[3,5]$

surface albedo-..The fraction of solar radiation incident on the Earth's surface that is reflected by it. Reflectivity varies with ground cover, and during the winter months it varies greatly with the amount of snow cover (depth and areal extent), Roughness of terrain, moisture content, solar angle, and angular and spectral distribution of ground-level irradiations are other factors affecting surface albedo. $[3,5]$

surface water-All water naturally open to the atmosphere. [140]

swamp--A type of wetland that is dominated by woody vegetation and does not accumulate appreciable peat deposits; it may be fresh- or saltwater, and tidal or nontidal. [140]

tephra-Any rock materia! produced by a volcano. [100]

terrestrial radiation-.. The total infrared radiation emitted by the Earth and its atmospliere in the temperature range of $-200-300 \mathrm{~K}$. Because the Earth is nearly a perfect radiator, the radiation from its surface varies as the fourth power of the surface's absolute temperature. Terrestrial radiation provides a major part of the potential energy changes necessary to drive the atmospheric wind system and is responsible for maintaining the surface air temperature within limits for livability. $[92,127,128]$

thermocline-A transition layer of water in the ocean, with a steeper vertical temperature gradient than that found in the layers of ocean above and below. The permanent thermocline separates the warm mixed surface layer of the ocean from the cold deep ocean water, and is found between 100- and $1000-\mathrm{m}$ depths. The thermocline first appears at the $55-60^{\circ} \mathrm{N}$ and $\mathrm{S}$ latitudes, where it forms a horizontal separation between temperate and polar 
waters. The thermocline reaches its maximum depth at mid-latitudes and is shallowest at the equator and at its northern and southern limits. The thermocline is stably stratified, and transfer of water and carbon dioxide across this zone occurs very slowly. Thus, the thermocline acts as a barrier to the downward mixing of carbon dioxide. $[93,94]$

thermohaline-Refers to the combined effects of temperature and salinity that contribute to density variations in the oceans. [100]

tidal marsh-Low, flat marshlands traversed by channels and tidal hollows and subject to tidal innundation; normally, the only vegetation present are salt-tolerant bushes and grasses. [140]

trace gas--A minor constituent of the atmosphere. The most important trace gases contributing to the greenhouse effect are water vapor, carbon dioxide, ozone, methane, ammonia, nitric acid, nitrous oxide, ethylene, sulfur dioxide, nitric oxide, dichlorofluoromethane or Freon 12, trichlorofluoromethane or Freon 11, methyl chloride, carbon monoxide, and carbon tetrachloride. $[95,96]$

transient tracers-Chemical elements (often radioactive) or compounds that have finite lifetimes. Atmospheric testing of nuclear weapons from the mid-1950s to the early 1960s released large quantities of radionuclides to the atmosphere. Atmosphere-ocean exchange processes have transferred some of these elements to the oceans. Studying the behavior and distribution of these specific isotopes and other chemical tracers in the ocean will provide information on: residence times of the water and its dissolved components in gyres, basins, etc.; the mode and rate of formation and the subsequent spreading rates of specific water types, such as the polar water of the Norwegian and Greenland Seas; deepocean circulation and ocean-mixing processes, such as adrection and upwelling; and the flux of anthropogenic carbon dioxide into the ocean through its correlation with several different transient tracers. $[98,99]$

transpiration-The process in plants by which water is taken up by the roots and released as water vapor by the leaves. The term can also be applied to the quantity of water thus dissipated. $[80,140]$

tree rings--Annual growth increments of trees that indicate, among other factors, the climatic conditions that enhance or limit growth. Tree ring widths and indexes have been used to search for solarterrestrial relationships and climatic cycles and to reconstruct past climates. See also 

40]

trophic level-A segment of the food chain in which all organisms obtain food and energy in, basically, the same manner (e.g., photosynthesis, herbivory, or carnivory) and in which all organisms are the same number of links from the photosynthetic segment. $[100,130]$

tropopause-The boundary between the troposphere and the stratosphere (about $8 \mathrm{~km}$ in polar regions and about $15 \mathrm{~km}$ in tropical regions), usually characterized by an abrupt change of lapse rate. The regions above the troposphere have increased atmospheric stability than those below. The tropopause marks the vertical limit of most clouds and storms. $[9,127]$

troposphere-The inner layer of the atmosphere below about $15 \mathrm{~km}$, within which there is normally a steady decrease of temperature with increasing altitude. Nearly all clouds form and weather conditions manifest themselves within this region, and its thermal structure is caused primarily by the heating of the Earth's surface by solar radiation, followed by heat transfer by turbulent mixing and convection. [9]

tundra-A type of ecosystem dominated by lichens, mosses, grasses, and woody plants. It is found at high latitudes (arctic tundra) and high altitudes (alpine tundra). Arctic tundra is underlain by permafrost and usually very wet. [140]

turnover rate- The fraction of the total amount of mass (e.g., carbon) in a given pool or reservoir that is released from or that enters the pool in a given length of time. The turnover rate of carbon is of ten expressed as $\mathrm{GtC} /$ year. [10]

upwelling-The vertical motion of water in the ocean by which subsurface water of lower temperature and greater density moves toward the surface of the ocean. Upwelling occurs most commonly among the western coastlines of continents, but may occur anywhere in the ocean. Upwelling results when winds blowing nearly parallel to a continental coastline transport the light surface water away from the coast. Subsurface water of greater density and lower temperature replaces the surface water, and exerts a considerable influence on the weather of coastal regions. Carbon dioxide is transferred to the atmosphere in regions of upwelling. This is especially important in the Pacific equatorial regions, where $1-2 \mathrm{GtC} /$ year may be released to the atmosphere. Upwelling also results in increased ocean productivity by transporting nutrient-rich waters to the surface layer of the ocean. [97] 
vapor-The gaseous phase of substances that are liquid or solid at atmospheric pressure (e.g., steam). [140]

varve-A layer of sediment deposited in lakes during one year. Each layer consists of two parts, which are deposited at different seasons and which differ in color and texture; thus, the layers can be counted and measured. In a complete series, the number of layers gives the date on which the ground was vacated by the retreating ice. [101]

Walker cell--A zonal circulation of the atmosphere confined to equatorial regions and driven principally by the oseanic temperature gradient. In the Pacific, air flows westward from the colder, eastern area to the warm, western ocean, where it acquires warmth and moisture and subsequently rises. A return flow aloft and subsidence over the eastern ocean complete the cell. $[65,74]$

water stress effect-The closing of the stomata by a plant in response to excessive water loss through transpiration or in response to drought conditions. The stomatal closing reduces $\mathrm{CO}_{2}$ uptake as well as water loss, thus decreasing the photosynthetic rate. However, under conditions of elevated $\mathrm{CO}_{2}$ concentration, the $\mathrm{CO}_{2}$ gradient between the atmosphere and the leaf is higher than under ambient conditions, and $\mathrm{CO}_{2}$ can pass through partially closed stomates at a rate similar to that under conditions of lower $\mathrm{CO}_{2}$ and open stomates. The humidity gradient remains the same at higher $\mathrm{CO}_{2}$, and transpiration is impeded. The net result is improved water-use efficiency by some plants. $[21,72]$

water table-The level of groundwater. [140]

water-use efficiency-A measure of the amount of water used by plants per unit of plant material produced. The term can be applied at the leaf, whole-plant, and ecosystem levels. At the leaf level, it is more precisely referred to as the instantaneous transpiration efficiency, the $\mathrm{CO}_{2}$ assimilation rate (photosynthesis) divided by the transpiration rate (the moles of $\mathrm{CO}_{2}$ taken up divided by the moles of water lost through transpiration in a unit of time per unit leaf area). At the whole-plant level, it is more precisely referred to as the growth water-use efticlency, the units of dry matter synthesized divided by the units of water lost. At the ecosystem level, it is more precisely referred to as the crop water-use efficiency, the grams of dry weight gained by plants during the growing season per unit land area divided by the millimeters of water lost (including evaporation directly from the soil). [136, 137]

water vapor-Water present in the atmosphere in gaseous form; the source of all forms of condensation and 
precipitation. Water vapor, clouds, and carbon dioxide are the main atmospheric components in the exchange of terrestrial radiation in the troposphere, serving as a regulator of planetary temperatures via the greenhouse effect. Approximately 50 percent of the atmosphere's moisture lies within about 1.84 $\mathrm{km}$ of the earth's surface, and only a minute fraction of the total occurs above the tropopause $[74,127]$

water vapor feedback-A process in which an increase in the amount of water vapor increases the atmosphere's absorption of longwave radiation, thereby contrituting to a werming of the atmosphere. Warming, in turn, may result in increased evaporation and an increase in the initial water vapor anomaly. This feedback, along with carbon dioxide, is responsible for the greenhouse effect and operates virtually continuously in the atmosphere. [74]

weather-.-The instantaneous state of the global atmosphereocean-cryosphere system. $[3,25]$

West Antarctic Ice Sheet--See ice sheet

wetlands-An area that is regularly saturated by surface water or groundwater and subsequently is characterized by a prevalence of vegetation that is adapted for life in saturated-soil conditions. [140]

zonally-averaged models-Statistical-dynamical or energybalance models in which only the latitudinally averaged quantities are determined and the effects of the longitudinally varying transports are determined parametrically. Abbreviated as ZAM. [54]

zooplankton-That portion of the plankton community comprised of tiny aquatic animals eaten by fish. [140] 
Table 1. Intermational System of Units (SI): Preflixes

\begin{tabular}{lcc}
\hline Prefix & $\begin{array}{c}\text { SI } \\
\text { Symbol }\end{array}$ & $\begin{array}{c}\text { Multiplication } \\
\text { Factor }\end{array}$ \\
\hline exa & $\mathrm{E}$ & $10^{18}$ \\
peta & $\mathrm{P}$ & $10^{15}$ \\
tera & $\mathrm{T}$ & $10^{12}$ \\
giga & $\mathrm{G}$ & $10^{9}$ \\
mega & $\mathrm{M}$ & $10^{6}$ \\
kilo & $\mathrm{k}$ & $10^{3}$ \\
hecto & $\mathrm{h}$ & $10^{2}$ \\
deka & $\mathrm{da}$ & $10^{-1}$ \\
deci & $\mathrm{d}$ & $10^{-1}$ \\
centi & $\mathrm{c}$ & $10^{-2}$ \\
milli & $\mathrm{m}$ & $10^{-3}$ \\
micro & $\mu$ & $10^{-6}$ \\
nano & $\mathrm{n}$ & $10^{-9}$ \\
pico & $\mathrm{p}$ & $10^{-12}$ \\
femto & $\mathrm{f}$ & $10^{-15}$ \\
atto & $\mathrm{a}$ & $10^{-18}$ \\
\hline
\end{tabular}


Table 2. Useful Quantities in $\mathrm{CO}_{2}$ Research

\begin{tabular}{lllr}
\hline \multicolumn{1}{c}{ Quantity } & Symbol* & \multicolumn{1}{c}{ Value } & Source \\
\hline Solar constant & $f$ & $1.375 \mathrm{~kW} / \mathrm{m}^{2}$ & 1 \\
Earth mass & $M$ & $5.976 \times 10^{24} \mathrm{~kg}$ & 2 \\
Equatorial radius & $a$ & $6.378 \times 10^{6} \mathrm{~m}$ & 2 \\
Polar radius & $c$ & $6.357 \times 10^{6} \mathrm{~m}$ & 2 \\
Mean radius & $R$ & $6.371 \times 10^{6} \mathrm{~m}$ & 3 \\
Surface area & $A_{e}$ & $5.101 \times 10^{14} \mathrm{~m}^{2}$ & 4 \\
Land area & $A_{l}$ & $1.481 \times 10^{14} \mathrm{~m}^{2}$ & 5 \\
Ocean area & $A_{s}$ & $3.620 \times 10^{14} \mathrm{~m}^{2}$ & 6 \\
Ice sheets and & $I_{s}$ & $0.14 \times 10^{14} \mathrm{~m}^{2}$ & 11 \\
$\quad$ glaciers area & & & \\
Mean land slevation & $h_{l}$ & $840 \mathrm{~m}$ & 5 \\
Mean ocean depth & $h_{s}$ & $3730 \mathrm{~m}$ & 7 \\
Mean ocean volume & $V_{s}$ & $1.350 \times 10^{18} \mathrm{~m}^{3}$ & 6 \\
Ocean mass & $M_{s}$ & $1.384 \times 10^{21} \mathrm{~kg}$ & 8 \\
Mass of atmosphere & $M_{a}$ & $5.137 \times 10^{18} \mathrm{~kg}$ & 9 \\
Equatorial surface & $g$ & $9.780 \mathrm{~m} / \mathrm{s}^{2}$ & 2 \\
$\quad$ gravity & & & \\
\hline
\end{tabular}
below.

"Symbols generally follow reference standards used in 10

\section{Sources and Notes:}

1. Hoyt, D. V. 1979. "The Smithsonian Astrophysical Observatory Solar Constant Program," Rev. Geophys. Space Physics 17: 427-458.

2. Press, F. and R. Siever, 1974. Earth, W. H. Freeman and Company, San Francisco.

3. For sphere of earth's volume.

4. Calculated from land and ocean data cited here.

5. Ridley, B. K. 1979. The Physical Environment, Ellis Horwood, Ltd., West Sussex, England.

6. Menard, H. W. and S. M. Smith, 1966. "Hypsometry of Ocean Basin Provinces," J. Geophys. Res. 71: 4305-4325, adopted as reference standard by Bolin (10).

7. Calculated from volume and area data cited here.

8. Calculated from volume data cited here plus density of $1025 \mathrm{~kg} / \mathrm{m}^{3}$; adopted as reference standard by Bolin (10).

9. Trenberth, K. E. 1981. "Seasonal Variations in Global Sea-Level Pressure and the Total Mass of the Atmosphere," J. Geophys. Res. 86: 5238-5246; this supercedes value adopted as reference standard by Bolin (10).

10. Bolin, B., ed., 1981. Carbon Cycle Modelling, SCOPE 16, John Wiley \& Sons, New York.

11. U.S. Department of Energy. 1985. Glaciers, Ice Sheets, and Sea Level: Effect of a $\mathrm{CO}_{2}$-Induced Climatic Change. M. F. Meier, ed. DOE/ER-60235-1. Carbon Dioxide Research Division, Office of Basic Energy Sciences, Washington, D.C.

Modified from: Clark, W. C. (ed.) 1982. Carbon Dioxide Review: 1982, p. 469, Oxford University Press, New York. 
Table 3. Common Conversion Factors

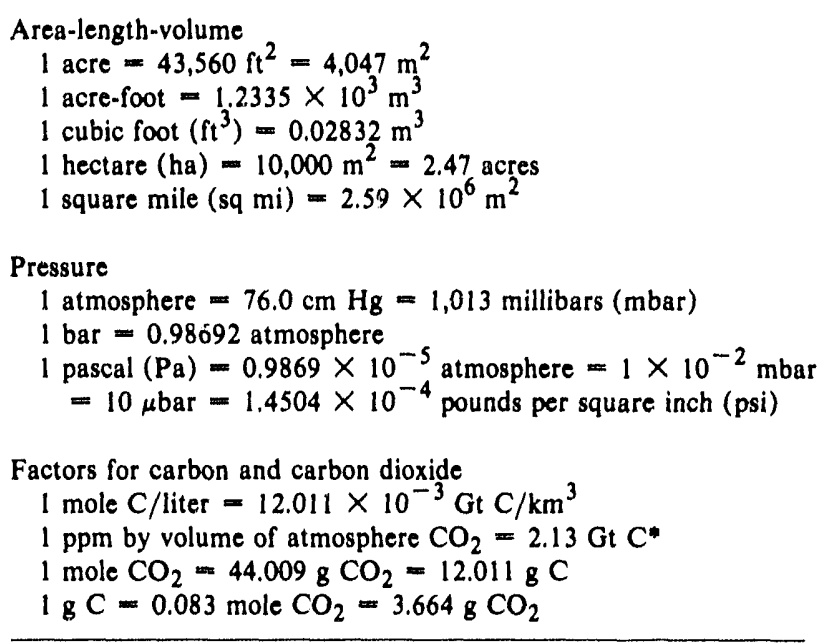

*Uses atmospheric mass from Table 2.

Modified from: Clark, W. C. (ed.) 1982. Carbon Dioxide Review: 1982, p. 467, Oxford University Press, New York. 


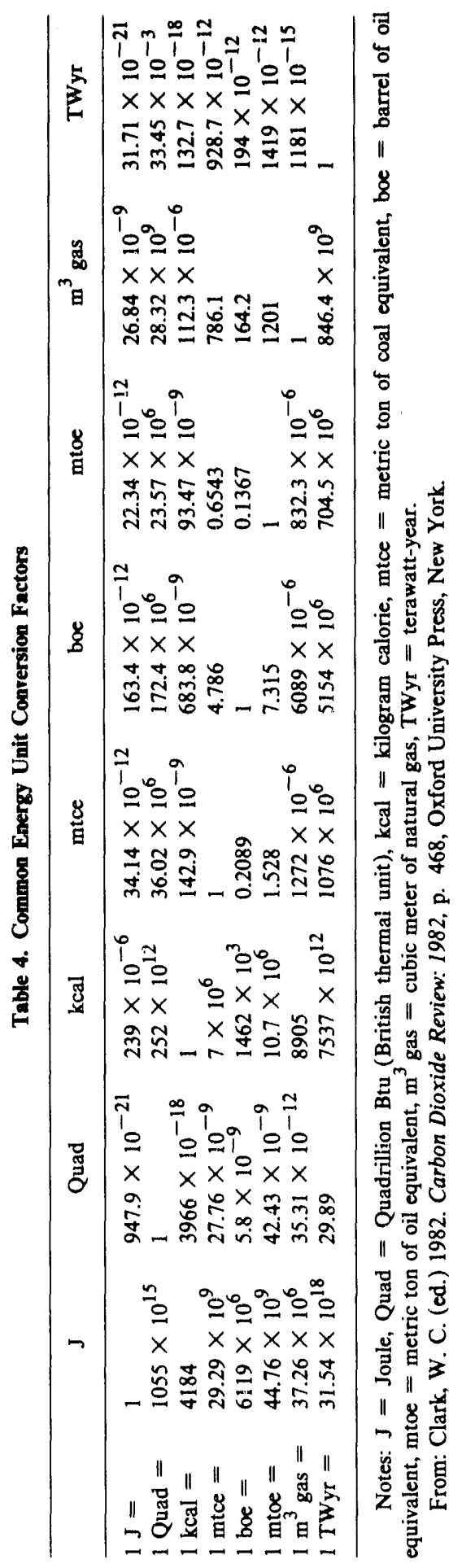


Table 5. Geologic Time Scales

\begin{tabular}{cllc}
\hline Era & Period & \multicolumn{1}{c}{ Epoch } & $\begin{array}{c}\text { Beginning } \\
\text { (Millions of Years } \\
\text { Before Present) }\end{array}$ \\
\hline Cenozoic & Quarternary & Recent (Holocene) & 0.01 \\
& Tertiary & Pleistocene & $2-3$ \\
& & Pliocene & 5 \\
& & Miocene & 25 \\
Mesozoic & Oligocene & 37 \\
& & Eocene & 54 \\
Paleozoic & Cretaceous & Paleocene & 65 \\
& Jurassic & & 135 \\
& Triassic & & 190 \\
& Permian & & 225 \\
& Carboniferous & & 280 \\
& Devonian & & 345 \\
& Silurian & & 400 \\
& Ordovician & & 440 \\
& Cambrian & & 500 \\
Precambrian & & 570 \\
& & & $>570$ \\
\hline
\end{tabular}




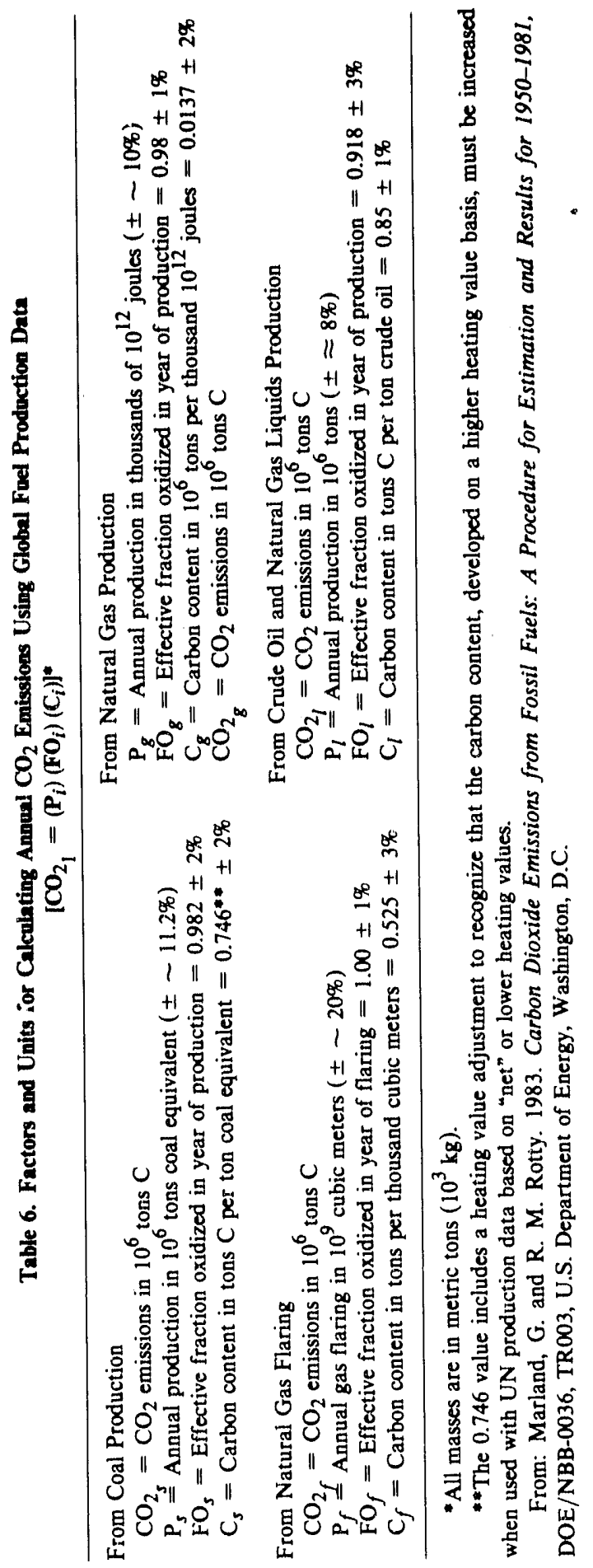




\begin{tabular}{|c|c|}
\hline AAAS & American Association for the Advancement of Science \\
\hline B.P. & Before Present \\
\hline BRW & Barrow Observatory, Barrow, Alaska \\
\hline CDIAC & Carbon Dioxide Information Analysis Center \\
\hline CIAP & Climate Impact Assessment Program \\
\hline CLIMAP & Climate Long-Range Investigation Mapping and Prediction \\
\hline COSPAR & Committee on Space Research \\
\hline DOE & Department of Energy \\
\hline ENSO & El Niño Southern Oscillation \\
\hline $\mathrm{FAO}$ & Food and Agriculture Organization of the United Nations \\
\hline FGGE & First Global GARP Experiment \\
\hline GAMETAG & $\begin{array}{l}\text { Global Atmospheric Measurements Experiment of } \\
\text { Tropospheric Aerosols and Gases }\end{array}$ \\
\hline GARP & Global Atmosphere Research Project \\
\hline GATE & GARP Atlantic Tropical Experiment \\
\hline GCM & General Circulation Model \\
\hline GEOSECS & Geochemical Ocean Sections Siudy \\
\hline GFDL & Geophysical Fluid Dynamics Laboratory \\
\hline GISP & Greenland Ice Sheet Program \\
\hline GISS & Goddard Institute for Space Sciences \\
\hline GOFS & Global Ocean Flux Study \\
\hline GMCC & Geophysical Monitoring for Climatic Change \\
\hline GSFC & Goddard Space Flight Center \\
\hline IAMAP & $\begin{array}{l}\text { International Association of Meteorology and } \\
\text { Atmospheric Physics }\end{array}$ \\
\hline ICSU & International Council of Scientific Unions \\
\hline IGBP & International Geosphere-Biosphere Programme \\
\hline IGY & International Geophysical Year \\
\hline IR & Infrared Radiation \\
\hline ISCCP & International Satellite Cloud Climatology Program \\
\hline ISLSCP & $\begin{array}{l}\text { International Satellite Land-Surface } \\
\text { Climatology Project }\end{array}$ \\
\hline lat. & Latitude \\
\hline long. & Longitude \\
\hline MLO & Mauna Loa Observatory, Hawaii \\
\hline MSL & Mean Sea Level \\
\hline M-region & Maunder Region \\
\hline NAS & National Academy of Sciences \\
\hline NASA & National Aeronautics and Space Administration \\
\hline NATO & North Atlantic Treaty Organization \\
\hline NBS & National Bureau of Standards \\
\hline NCAR & National Center for Atmospheric Research \\
\hline $\mathrm{NCDC}$ & National Climatic Data Center \\
\hline NH & Northern Hemisphere \\
\hline NIST & National Institute of Standards and Technology \\
\hline NOAA & National Oceanic and Atmospheric Administration \\
\hline NODC & National Oceanographic Data Center \\
\hline NRL & Naval Research Laboratory \\
\hline NSF & National Science Foundation \\
\hline NTIS & National Technical Information Service \\
\hline ONR & Office of Naval Research \\
\hline ppmiv & $\begin{array}{l}\text { Parts per Million by Volume (sometimes designated } \\
\text { simply as ppm) }\end{array}$ \\
\hline SCOPE & Scientific Committee on Problems of the Environment \\
\hline SEAREX & Sea-Air Exchange Program \\
\hline
\end{tabular}


Table 7 (continued)

\begin{tabular}{ll} 
SH & Southern Hemisphere \\
SIO & Scripps Institution of Oceanography \\
SMM & Solar Maximum Mission \\
SMO & Samoa Observatory, American Samoa \\
SPO & South Pole Observatory, Antarctica \\
TOGA & Tropical Oceans and Global Atmosphere \\
TTO & Transient Tracers in the Ocean \\
UNESCO & United Nations Educational Scientific and Cultural \\
& Organization \\
USDA & United States Department of Agriculture \\
USGS & United States Geological Survey \\
WDC & World Data Center \\
WMO & World Meteorological Organization \\
WOCE & World Ocean Circulation Experiment \\
& \\
& \multicolumn{1}{c}{$\quad$ INDEXES } \\
D.V.I. & H. H. Lamb's Dust Veil Index \\
R & Wolf sunspot number \\
R & Zurich relative sunspot number \\
VEI & Volcano Explosivity Index
\end{tabular}




\section{REFERENCES}

1. Hammer, C. U., H. B. Clausen, and W. Dansgaard. 1980. "Greenland Ice Sheet Evidence of Postglacial Volcanism and Its Climatic Impact," Nature 288: 230-235.

2. Hammer, C. U. 1977. "Past Volcanism Revealed by Greenland Ice Sheet Impurities," Nature 270: 482-486.

3. Huschke, R. E., ed. 1959. Glossary of Meteorology. American Meteorological Society, Boston.

4. Grobecker, A. J., S. C. Coroniti, and E. W. Hewson. 1980. "Atmospheric Pollution," pp. $51-60$ in Parker, S. P., ed. McGraw-Hill Encyclopedia of Ocean and Atmospheric Sciences. McGraw-Hill Book Company, New York.

5. Budyko. M. I. 1974. Climate and Life. Academic Press, New York.

6. Brewer, P. G. 1982. "Carbon Dioxide and Ocean Chemistry," pp. 361-384 in Beatty, N. B., ed., Proceedings Workshop on First Detection of Carbon Dioxide Effects. DOE/CONF-8106214, U.S. Department of Energy, Washington, D.C.

7. Bradshaw, A. L., P. G. Brewer, D. K. Shafer, and R. T, Williams. 1981. "Measurements of Total Carbon Dioxide and Alkalinity by Potentiometric Titration in the GEOSECS Program," Earth and Planetary Science Letters 55: 99-115.

8. Baes, C. F., Jr. 1982. "Effects of Ocean Chemistry and Biology on Atmospheric Carbon Dioxide," pp. 189-211 in Clark, W. C., ed., Carbon Dioxide Review: 1982. Oxford University Press, New York.

9. Murgatroyd. R. J. 1980. "Atmosphere," pp. 31-33 in Parker, S. P., ed., McGraw-Hill Encyclopedia of Ocean and Atmospheric Sciences, McGraw-Hill Book Company, New York.

10. Whittaker, R. H., G. E. Likens, and H. Lieth. 1975. "Scope and Purpose of This Volume," pp. 3-5 in Lieth, H., and R. H. Whittaker, eds., Primary Productivity of the Biosphere. Springer-Verlag, New York.

11. McNaughton, S. J., and L. L. Wólf. 1979. General Ecology. Second Edition. Hold, Rinehart, and Winstun, New York.

12. Bolin, B. 1981. "Standardization of Notations and Procedures," pp. 81-85 in Bolin, B., ed. Carbon Cycle Modelling. SCOPE 16. John Wiley and Sons, Chichester, England.

13. Baes, C. F., Jr. 1981. The Response of the Oceans to Increasing Atmospheric Carbon Dioxide. ORAU/IEA-81-6(M). Oak Ridge Associated Universities, Institute for Energy Analysis, Oak Ridge, Tennessee. 
14. Revelle, R, and H. E. Suess. 1957. "Carbon Dioxide Exchange Between Atmosphere and Ocean and the Question of an Increase of Atmospheric $\mathrm{CO}_{2}$ During the Past Decades," Tellus 9(1): 18-27.

15. Takahashi, T. 1979. "Carbon Dioxide Chemistry in Ocean Water," pp. 63-71 in Elliott, W. P. and L. Machta, eds., Workshop on the Global Effects of Carbon Dioxide from Fossil Fuels. CONF-770385. National Technical Information Service, Springfield, Virginia.

16. Broecker, W. S., T. Takahashi, H. J. Simpson, and T.-H. Peng. 1979. "Fate of Fossil Fuel Carbon Dioxide and the Global Carbon Budget," Science 206: 409-418.

17. Delcourt, H, R, and W. F, Harris, 1980, "Carbon Budget of the Southeastern U.S. Biota: Analysis of Historical Change in Trend from Source to Sink," Science 210: 321-323.

18. Bolin, B. 1975. "A Critical Appraisal of Models for the Carbon Cycle," Appendix 8, pp. 225-235 in The Physical Basis of Climate and Climate Modelling. GARP Report 16, WMO/ICSU, Geneva, Switzerland.

19. Bolin, B., E. T. Degens, P. Duvigneaud, and S. Kempe. 1979. "The Global Biogeochemical Carbon Cycle," pp. 1-56 in Bolin, B., et al, eds. The Global Carbon Cycle. SCOPE 13. John Wiley and Sons, Chichester, England.

20. Olson, J. S., J. A. Watts, and L. J. Allison. 1983. Carbon in Live Vegetation of Major World Ecosystems. DOE/NBB-0037. U.S. Department of Energy, Washington, D.C. [Also published as ORNL-5862, Oak Ridge National Laboratory, Oak Ridge, Tennessee. 1984.].

21. Rosenberg, N. J. 1981. "The Increasing $\mathrm{CO}_{2}$ Concentration in the Atmosphere and Its Implication on Agricultural Productivity. 1. Effects on Photosynthesis, Transpiration and Water Use Efficiency," Climate Change 3: 265-279.

22. Olson, J. S. 1982. "Earth's Vegetation and Atmospheric Carbon Dioxide," pp. 388-398 in Clark, W. C., ed. Carbon Dioxide Review: 1982. Oxford University Press, New York.

23. Heede. R. 1983. A World Geography of Recoverable Carbon Resources in the Context of Possible Climatic Change. NCAR/CT-72, University of Colorado and National Center for Atmospheric Research, Boulder, Colorado.

24. Kutzbach, J. E, 1977. "Climatic Change," pp. 85-87 in Parker, S. P., ed. McGraw-Hill Encyclopedia of Ocean and Atmospheric Sciences. McGraw-Hill Book Company, New York.

25. National Research Council. 1975. Understanding Climatic Change, A Program for Action. National Academy of Sciences, Washington, D.C.

26. Gates, W. L. 1981. "Physical Basis of Climate," pp. 3-19 in Berger, A., ed. Climatic Variations and 
Variability: Facts and Theories. D. Reidel Publishing Company, Dordrecht, Holland.

27. Griffiths, J, F, and D. M. Driscoll. 1982. Survey of Climatology. Charles E. Merrill Publishing Company, Columbus, Ohio.

28. Lamb, H. H. 1982. Climate, History and the Modern World. Methuen Press, New York.

29. Ludlam, F. H. 1980. "Cloud," pp. $94-99$ in Parker, S. P., ed. McGraw-Hill Encyclopedia of Ocean and Atmospheric Sciences, McGraw-Hill Book Company, New York.

30. Houghton, J, T. 1984. The Global Climate. Cambridge University Press, United Kingdom.

31. MacDonald, G. J, ed. 1982. The Long-Term Impacts of Increasing Atmospheric Carbon Dioxide Levels, Ballinger Publishing Company, Cambridge, Massachusetts.

32. Manabe, S. and R, F. Strickler, 1964. "Thermal Equilibrium of the Atmosphere with a Convective Adjustment," Journal of the Atmospheric Sciences 21: 361-365.

33. Flohn, H. 1981, Life on a Warmer Earth, Possi. ble Climatic Consequences of Man-Made Global Warming. Executive Report 3, International Institute for Applied Systems Analysis, Laxenburg, Austria,

34. WMO, Environmental Pollution Monitoring Programme. 1981. Report of the WMO/UNEP/ICSU Meeting on Instruments, Standardization, and Measurement Techniques for Atmospheric $\mathrm{CO}_{2}$. Geneva, Switzerland, September 8-11, 1981. World Meteorological Organization, Geneva, Switzerland.

35. Baumgartner, A. and $M$. Kirchner. 1980. "Impacts due to Deforestation," pp, 305-316 in Bach, W., J. Pankrath, and J. Williams, eds. Interactions of Energy and Climate. D. Reidel Publishing Co., Dordrecht, Holland.

36. Scott, G. A. J. 1974. "Effects of Shifting Cultivation in the Gran Pajonal, Eastern Peru," Proc, Assoc. Amer. Geog. 6: 58-61.

37. Schulman, E. 1970. "Tree-Ring Evidence for Climatic Changes," pp. 209-219 in Shapley, H., ed. Climatic Change, Evidence, Causes, and Effects. Harvard University Press, Cambridge, Massachusetts.

38. Fritts, H. C., G. R. Lofgren, and G. A. Gordon. 1981. "Reconstructing Seasonal to Century Time Scale Variations in Climate from Tree-Ring Evidence, ${ }^{n} \mathrm{pp}$. 139-161 in Wigley, T. M. L., M. J. Ingram, and G. Farmer, eds. Climate and History: Studies in Past Climates and Their Impact on Man. Cambridge University Press, New York.

39. Fritts, H. C. 1966. "Growth-Rings of Trees: Their Correlation with Climate," Science 154: 973-979.

40. Fritts, H. C. 1976. Tree Rings and Climate. Academic Press, London.

41. Hughes, M. K., P. M. Kelly, J. R. Pilcher, and V. C. LaMarche, Jr., eds. 1982. Climate from Tree Rings. Cambridge University Press, New York. 
42. Otterman, J. 1977. "Anthropogenic Impact on the Albedo of the Earth, " Climatic Change 1: 137-155.

43. Capurro, L, R. A. 1970. Oceanography for Practicing Engineers. Barnes and Noble, Inc., New York.

44. Lamb, H. H. 1970. "Volcanic Dust in the Atmosphere with a Chronology and Assessment of Its Meteorological Significance," Phil. Trans. Roy. Soc. London, Ser, A. 266: 425-533.

45. Quinn, W. H. 1974. "Monitoring and Predicting El Niño Invasions, ${ }^{n}$ J. Appl. Meteorol. 13: 825-830.

46. Cowles, T, J., R, T. Barber, and O. Guillen. 1977. "Biological Consequences of the 1975 El Niño," Science 195: 285 287.

47. Ramage, C. S. and A. M. Hori. 1981. "Meteorological Aspects of E! Nino," Monthly Weather Review 109: $1827-1835$.

48. Wyrtki, K., E. Stroup, W. Patzert, R. Williams, and W. Quinn. 1976. "Predicting and Observing El Niño, ${ }^{n}$ Science 191: 343-346.

49. North, G, R., R, F. Cahalan, and J. A. Coakley. 1981. "Energy Balance Climate Models," Rev. Geophys. Space Phys. 19: 91-121.

50. Kellogg, W. W. and M. Mead. 1977. The Almosphere: Endangered and Endangering. Fogarty International Center Proceedings No, 39, National Institutes of Health, Washington, D.C.

51. Klein, W. H. 1982. "Detecting Carbon Dioxide Effects on Climate," pp. 215-242 in Clark, W. C., ed. Carbon Dioxide Review: 1982. Oxford University Press, New York.

52. Wigley, T. M. L., and P. D. Jones. 1981. "Detecting $\mathrm{CO}_{2}$-Induced Climatic Change," Nature 292: 205-208.

53. MacCracken, M. C. 1982. "The First Detection of Carbon Dioxide Effects: Workshop Summary," pp. 3-44 in Beatty, N. B., ed. Proc. Workshop on First Detection of Carbon Dioxide Effects. DOE/ CONF-8106214, U.S. Department of Energy, Washington, D.C.

54. Schlesinger, M. E. 1983. "A Review of Climate Models and Their Simulation of $\mathrm{CO}_{2}$-Induced Warming," International Journal of Environmental Studies 20: 103-114.

55. Smith, G. D., ed. The Cambridge Encyclopedia of Earth Sciences. Cambridge University Press, New York.

56. Westlake, D. F. 1963. "Comparisons of Plant Productivity," Biological Reviews 38: 385-425.

57. Macfadyen, A. 1974. "Biological Productivity," pp. 61-63 in Lapedes, D. N., ed. McGraw-Hill Encyclopedia of Earth Sciences. Cambridge IJniversity Press, New York.

58. Vincent, C. E. 1981. "The Oceans," pp. 311-324 in Smith, D. G., ed. The Cambridge Encyclopedia of Earth Sciences. Cambridge University Press, New York.

59. Sayre, A. M. and R. K. Linsley, 1980. "Hydrology," pp. 186-187 in Parker, S. P., ed. 
McGraw-HIIl Encyclopedia of Ocean and Atmospheric Sciences. McGraw-Hill Book Company, New York.

60. WMO/ICSU. 1975. The Physical Basis of Climate and Climate Modelling. GARP Publication Series No. 16, World Meteorological Organization, Geneva, Switzerland.

61. Hummel, J. R. and R. A. Reck. 1979. "A Global Surface Albedo Model, ${ }^{\circ} J$, Appl. Meteorol. 18(3): 239-253.

62. Fritz, S. 1980, "Insolation," pp. 206 207 in Parker, S. P., ed. McGraw-Hill Encyclopedia of Ocean and Atmospheric Sciences. McGraw-Hill Book Company, New York.

63. Rumney, G. R. 1968. Climatology and the World's Climates. The Macmillan Company, New York.

64. Stone, P. H., and J. H. Carlson. 1979. "Atmospheric Lapse Rate Regimes and Their Parameterization," J. Atmospheric Sci. 36: $415-423$.

65. Feagle, R. G., and J. A. Businger. 1980. An Introduction to Atmospheric Physics. Second Edition. Academic Press, New York.

66. Keeling, C. D., R. B. Bacastow, and T. P. Whorf. 1982. "Measurements of the Concentration of Carbon Dioxide at Mauna Loa Observatory, Hawaii," pp. $377-383$ in Clark, W. C., ed. Carbon Dioxide Review: 1982. Oxford Uriversity Press, New York.

67. Hunt, L. M., and D. G. Groves, eds. 1965. A Glossary of Ocean Science and Undersea Technology' Terms. Compass Publications, Inc., Arlington, Virginia.

68. Birks, H. J. B. 1981. "The Use of Pollen Analysis in the Reconstruction of Past Climates: $A$ Review, ${ }^{n}$ pp. 111-138 in Wigley, T. M. L., M. J. Ingram, and G. Farmer, eds. Climate and History: Studies in Past Climates and Their Impact on Man. Cambridge University Press, New York.

69. Thewlis, J., ed. 1962. Encyclopaedic Dictionary of Physics. Pergamon Press, Oxford, England.

70. Riley, J. P. 1971. "The Dissolved Gases in Sea Water, Part 2. Carbon Dioxide," pp. 121-151 in Riley, J. P., and R. Chester, Introduction to Marine Chemistry. Academic Press, London.

71. Takahashi, T, 1961. "Carbon Dioxide in the Atmosphere and in Atlantic Ocean Water," J. Geophys. Res. 66(2): 477-494.

72. Lieth, H. 1963. "The Role of Vegetation in the Carbon Dioxide Content of the Atmosphere," J. Geophys. Res. 68(13): 3887-3898.

73. Cooper, C. F. 1982. "Food and Fiber in a World of Increasing Carbon Dioxide," pp. $299 \ldots 333$ in Clark, W. C., ed. Carbon Dioxide Review: 1982. Oxford University Press, New York.

74. Campbell, 1. M. 1977. Energy and the Atmosphere. A Physical-Chemical Approach. John Wiley and Sons, New York.

75. Kellogg, W. W. 1982, "Precipitation Trends on a Warmer Earth," pp. 35-45 in Reck, R. A., and J. R. 
Hummel, eds. Interpretation of Climate and Photochemical Models, Ozone, and Temperature Measure. ments. American Institute of Physics, New York.

76. Platt, R. B. 1974. "Environment," pp. 175-178 in Lapedes, D. M., ed. McGraw-Hill Encyclopedia of Science and Technology. Third Edition, McGraw-Hill Book Company, New York.

77. Odum, E. P. 1971. Fundame nials of Ecology. Third Edition. W. B. Saunders Co., Philadelphia, Pennsylvania.

78. Ingram, M. J., G. Farmer, and T. M. L. Wigley. 1981. "Past Climates and Their Impact on Man: A Review," pp. 1-50 in Wigley, T. M. L., M. J. Ingram, and G. Farmer, eds. Climate and History: Studies in Past Climates and Their Impact on Man. Cambridge University Press, New York.

79. Baes, C. F., Jr., H. E. Goeller, J. S. Olson, and R. M. Rotty. 1976. The Global Carbon Dioxide Problem. ORNL-5194, Oak Ridge National Laboratory, Oak Ridge, Tennessee.

80. Rosenberg, N. J. 1981. "Implications of Increasing $\mathrm{CO}_{2}$ in the Atmosphere on Agriculture Production: Direct and Indirect Effects," Proc. of a Symposium on the Carbon Dioxide Issue, American Chemical Society, Division of Petroleum Chemistry, Preprints 26(4): 1026-1037.

81. Pickard, G. L. 1975. Descriptive Physical Oceanography. Pergamon Press, New York.

82. Revelle, R., and W. Munk. 1977. "The Carbon Dioxide Cycle and the Biosphere," pp. 140-158 in Geophysics Study Committee, Energy and Climate. National Academy of Sciences, Washington, D.C.

83. Armentano, T. V., ed. 1980. The Role of Organic Soils in the World Carbon Cycle-Problem Analysis and Research Needs. CONF-7905135, The Institute of Ecology, Indianapolis, Indiana.

84. Post, W. M., W. R. Emanuel, P. J. Zinke, and A. G. Stangenberger. 1982. "Soil Carbon Pools and World Life Zones, ${ }^{n}$ Nature 298: 156-159.

85. Bacastow, R. B., J. A. Adams, C. D. Keeling, D. J. Moss, and T. F. Whorf. 1980. "Atmospheric Carbon Dioxide, the Southern Oscillation, and the Weak 1975 El Niño," Science 210: 66-68.

86. Bacastow, R. B. 1977. "Southern Oscillation Index and Atmospheric Carbon Dioxide," Nature 267: 650.

87. Pittock, A. B. and M. J. Salinger. 1982. "Towards Regional Scenarios for a $\mathrm{CO}_{2}$-Warmed Earth," Climatic Change 4: 23-40.

88. Chen, W. Y. 1982. "Assessment of Southern Oscillation Sea Level Pressure Changes," Monthly Weather Review 110: 800-807.

89. Keeling, C. D. 1979. "The Suess Effect: ${ }^{13} \mathrm{Carbon}-{ }^{14} \mathrm{Carbon}$ Interrelations," Environment International 2(6): 229-300.

90. Eddy, J. A. 1977. "Climate and the Changing Sun," Climatic Change 1: 173-190. 
91. Herman, J. R. and R. A. Goldberg. 1978. Sun, Weather, and Climate. National Aeronautics and Space Administration, Washington, D.C.

92. Kaplan, L. D. 1980. "Terrestrial Radiation," p. 493 in Parker, S. P., ed. McGraw-Hill Encyclopedia of Ocean and Atmospheric Sciences. McGrawHill Book Company, New York.

93. Plutchak, N. 1966. "Thermocline," pp. 911-913 in Fairbridge, R. W., ed. The Encyclopedia of Oceanography. Encyclopedia of Earth Sciences Series, Volume 1. Reinhold Publishing Co., New York.

94. Schule, J. J., Jr. 1974. "Thermocline," pp. 619-620 in Lapedes, D. N., ed. McGraw-Hill Encyclopedia of Environmental Science. McGraw-Hill Book Company, New York.

95. Wang, W., Y. Yung, A. Lacis, T. Mo, and J. Hansen. 1976. "Greenhouse Effects due to Man-Made Perturbations of Trace Gases," Science 194: 685.

96. Lacis, A., J. Hansen, P. Lee, T. Mitchell, and S. Ledbedeff. 1981. "Greenhouse Effect of Trace Gases, 1979-1980," Geophys. Res. Let. 8(10): 1035-1038.

97. LaFond, E. C. 1966. "Upwelling," pp. 957-959 in Fairbridge, R. W., ed. Encyclopedia of Oceanography. Encyclopedia of Earth Sciences Series, Volume 1. Reinhold Publishing Co., New York.

98. Gross, G. 1982. "North Atlantic Study of Transient Tracers in Oceans (NAS/TTO)," pp. 66, Research Proposal in Carbon Cycle Research Plan. DOE/ER-0142, U.S. Department of Energy, Washington, D.C.

99. Ostlund, H. G., W. S. Broecker, and C. G. H. Rooth. 1977. Transient Tracers in the Ocean. A Report to the International Decade of Ocean Exploration, National Science Foundation, Design Workshop, Feb. 10-12, 1977, LaMont Doherty Geological Observatory, Columbia University, Palisades, New York, p. 25 .

100. Parker, S. P., ed. 1984. McGraw-Hill Dictionary of Scientific and Technical Terms. 3rd ed. McGraw-Hill Book Company, New York.

101. Considine, D. M., ed. 1976. Van Nostrand's Scientific Encyclopedia. 5th ed. Van Nostrand Reinhold Company, New York.

102. Gary, M., R. McAfee, Jr., and C. L. Wolf, eds. 1974. Glossary of Geology. American Geological Institute, Falls Church, Virginia.

103. Little, R. J., and C. E. Jones. 1980. A Dictionary of Botany. Van Nostrand Reinhold Company, New York.

104. Gray, P. 1967. The Dictionary of the Biological Sciences. Van Nostrand Reinhold Company, New York.

105. Luther, F. M., and R. G. Ellingson. 1985. "Carbon Dioxide and the Radiation Budget," pp. 25-55 in MacCracken, M.C., and F. M. Luther, eds. Projecting the Climatic Effects of Increasing Carbon Dioxide. DOE/ER-0237, U.S. Department of Energy, Washington, D.C. 
106. Hoffert, M. I., and B. P. Flannery. 1985. "Model Projections of the Time-Dependent Response to Increasing Carbon Dioxide," pp. 149-190 in MacCracken, M. C., and F. M. Luther, eds. Projecting the Climatic Effects of Increasing Carbon Dioxide. DOE/ER-0237, U.S. Department of Energy, Washington D.C.

107. MacCracken, M. C. 1985. "Carbon Dioxide and Climate Change: Background and Overview," pp. 1-23 in MacCracken, M. C., and F. M. Luther, eds. Projecting the Climatic Effects of Increasing Carbon Dioxide. DOE/ER-0237, U.S. Department of Energy, Washington, D.C.

108. Baes, C. F. Jr., A. Bjorkstrom, and P. J. Mulholland. 1985. "Uptake of Carbon Dioxide by the Oceans," pp. 81-111 in Trabalka, J. R., ed. Atmospheric Carbon Dioxide and the Global Carbon Cycle. DOE/ER-0239, U.S. Department of Energy, Washington, D.C.

109. Wang, W-C., D. J. Wuebbles, and W. M. Washington. 1985. "Potential Climatic Effects of Perturbations Other Than Carbon Dioxide," pp. 191-236 in MacCracken, M. C., and F. M. Luther, eds. Projecting the Climatic Effects of Increasing Carbon Dioxide. DOE/ER-0237, U.S. Department of Energy, Washington, D.C.

110. Olson, J. S., R. M. Garrels, R. A. Berner, T. V. Armentano, M. I. Dyer, and D. H. Yaalon. 1985. "The Natural Carbon Cycle," pp. 175-213 in Trabalka, J. R., ed. Atmospheric Carbon Dioxide and the Global Carbon Cycle. DOE/ER-0239, U.S. Department of Energy, Washington, D.C.

111. Acock, B., and L. H. Aller, Jr. 1985. "Crop Responses to Elevated Carbon Dioxide Concen. trations," pp. 53-97 in Strain, B. R., and J. D. Cure, eds. Direct Effects of Increasing Carbon Dioxide on Vegetation. DOE/ER-0238, U.S. Department of Energy, Washington, D.C.

112. Lane, H. U., ed. 1986. The World Almanac and Book of Facts 1986. Newspaper Enterprise Assoc., New York, pp. 525--526.

113. Levey, J. S., and A. Greenhall, eds. 1986. The Concise Columbia Encyclopedia. Columbia University Press, New York.

114. Aubrey, D. G. 1985. "Recent Sea Levels from Tide Gauges: Problems and Prognosis, " pp. 73-91 in Meier, M. F., ed. Glaciers, Ice Sheets, and Sea Level: Effect of a $\mathrm{CO}_{2}$-Induced Climatic Change. DOE/ER/60235-1, U.S. Department oî Energy, Washington, D.C.

115. Bradley, R. S., and Jones, P. D. 1985. "Data Bases for Isolating the Effects of the Increasing Carbon Dioxide Concentration," pp. 29-53 in MacCracken, M. C., and F. J. Luther, eds. Detecting the Climatic Effects of Increasing Carbon Dioxide. DOE/ER-0235, U.S. Department of Energy, Washington, D.C. 
116. Usher, G. 1966. A Dictionary of Botany. Constable and Company Ltd., London.

117. Baker, B. B., W. R. Deebel, and R. D. Geisenderfer, eds. 1966. Glossary of Oceanographic Terms. Second edition. U.S. Naval Oceanographic Office, Wasinington, D.C.

118. Bates, R. L., and J. A. Jackson, eds. 1980. Glossary of Geology. Second edition. American Geological Institute, Falls Church, Virginia.

119. Collocott, T. C., and A. B. Dobson, eds. 1974. Dictionary of Science and Technology. W \& R Chambers Ltd., Edinburgh, Scotland.

120. Pfannkuch, H. 1969. Elsevier's Dictionary of Hydrogeology. Elsevier Publishing Company, Amsterdam, The Netherlands.

121. Clark, W. C., K. H. Cook, G. Marland, A. M. Weinberg, R. M. Rotty, P. R. Bell, L. J. Allison, and C. L. Cooper. 1982. "The Carbon Dioxide Question: Perspectives for 1982," pp. 3-44 in Clark, W. C., ed. Carbon Dioxide Review: 1982. Oxford University Press, New York.

122. Charles-Edwards, D. A., D. Doley, and G. M. Rimmington. 1986. Modelling Plant Growth and Development. Academic Press, New York.

123. U.S. Naval Oceanographic Office. 1966. Glossary of Oceanographic Terms, 2nd Ed. SP-35. U.S. Naval Oceanographic Office, Washington, D.C.

124. Hutter, Kolumban. 1983. Theoretical Glaciology. D. Reidel Publishing, Boston.

125. Sugden, D. E., and B. S. John. 1976. Glaciers and Landscape, A Geomorphological Approach. John Wiley \& Sons, New York.

126. Hill, M. N. 1966. The Sea, Vol. I. Interscience Publishers, New York.

127. Huschke, R. E. 1959. Glossary of Meteorology. American Meteorological Society, Boston.

128. McIntosh, D. H. 1963. Meteorological Glossary. Her Majesty's Stationery Office, London.

129. Fairbridge, R. W., ed. 1967. The Encyclopedia of Atmospheric Sciences and Astrogeology. Reinhold Publishing, New York.

130. Bates, R. L., and J. A. Jackson, eds. 1987. The Glossary of Geology, 3rd. Ed. American Geological Institute, Alexandria, Va.

131. Allaby, M. 1988. Dictionary of the Environment, 3rd Ed. Macmillan Reference Books, London.

132. Bolle, H.-J., W. Seiler, and B. Bolin. 1986. "Other Greenhouse Gases and Aerosols," Chap. 4 in Bolin, B., et al. The Greenhouse Effect, Climate Change, and Ecosystems. John Wiley \& Sons, New York.

133. Wuebbles, D. J., and J. Edmonds. 1988. $A$ Primer on Greenhouse Gases. DOE/NBB-0083, U.S. Department of Energy, Washington, D.C.

134. Mitchell, J. F. B. 1989. "The 'Greenhouse' Effect and Climate Change." Rev. Geophys. 27: $115-139$. 
135. Gates, W. L. 1985. "Modeling as a Means of Studying the Climate System," Chap. 3 in MacCracken, M. C., and F. M. Luther, eds. Projecting the Climatic Effects of Increasing Carbon Dioxide. DOE/ER-0237. U.S. Department of Energy, Washington, D.C.

136. Larcher, W. 1980. Physiological Plant Ecology, 2nd Ed. Springer-Verlag, New York.

137. Morison, J. I. L. 1985. "Sensitivity of Stomata and Water Use Efficiency to High $\mathrm{CO}_{2}$, Plant, Cell and Environment 8: 46\%-474.

138. Air \& Waste Management Association. 1989. A Dictionary of Waste Terms. Air \& Waste Management Association, Pittshurgh, Penn.

139. Air \& Waste Management Association. 1989. A Dictionary of Air Pollution Terms. Air \& Waste Management Association, Pittsburgh, Penn.

140. Office of Communications and Public Affairs. 1989. Glossary of Environmental Terms and Acronym List. U.S. Environmental Protection Agency, Washington, D.C.

141. Oliver, J. E., and R. W. Fairbridge. 1987. The Encyclopedia of Climatology. Van Nostrand Reinhold, New York. 


\section{APPENDIX}

The Carbon Dioxide Information Analysis Center (CDIAC), located within the Environmental Sciences Division of Oak Ridge National Laboratory, has been in operation since 1982. CDIAC provides information support to the international research, policy, and education communities for evaluation of complex environmental issues associated with elevated atmospheric $\mathrm{CO}_{2}$, including potential climate change.

Paul Kanciruk is Director of CDIAC. CDIAC activities include obtaining and evaluating data, articles and reports; producing digital numeric data and computer model packages (NDPs and CMPs); distributing $\mathrm{CO}_{2}$-related reports; and producing the newsletter CDIAC Communications, with a world-wide distribution to subscribers in more than 150 countries.

CDIAC is funded by the U.S. Department of Energy (DOE) to support its Carbon Dioxide Research Program (CDRP). The goal of the CDRP is to develop sound scientific information for policy formation and governmental action in response to changes of atmospheric $\mathrm{CO}_{2}$. The thrust of the CDRP during the past decade has been to (1) elucidate the processes that control the global carbon cycle and provide predictions of future atmospheric $\mathrm{CO}_{2}$ change, (2) develop data and models of the processes by which changes in the Earth's radiative balance may change climate at global and regional scales and predict rates of potential climate change, and (3) develop the data and models required to define and predict the combined effect of climate and $\mathrm{CO}_{2}$ on plants, crops, and ecosystems.

During 1989, the Program was moved from DOE's Office of Basic Energy Sciences into the Office of Health and Environmental Research. At the same time the Program was combined, with other atmospheric research activities, under the Atmospheric and Climate Research Division (ACRD). Ari Patrinos is the Acting Director of ACRD.

The mailing address for the Program is:

Carbon Dioxide Research Program

Atmospheric and Climate Research

Division, ER-76

U.S. Department of Energy

Washington, DC 20545 U.S.A. 


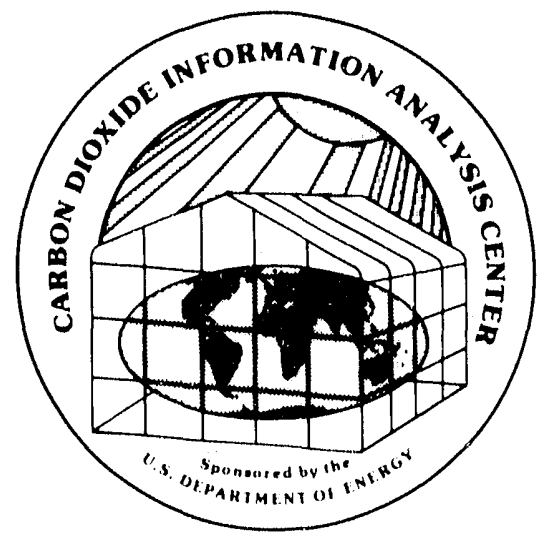

Carbon Dioxide Information Analysis Center Environmental Sciences Division

Oak Ridge National Laboratory

P.O. Box 2008

Oak Ridge, Tennessee 37831-6335 USA

Telephone 615-574-0390 or FTS 624-0390

BITNET: CDP@ORNLSTC

INTERNET: CDP@STC10.CTD.ORNL.GOV OMNET: CDIAC

FAX: $615-574-2232$ 


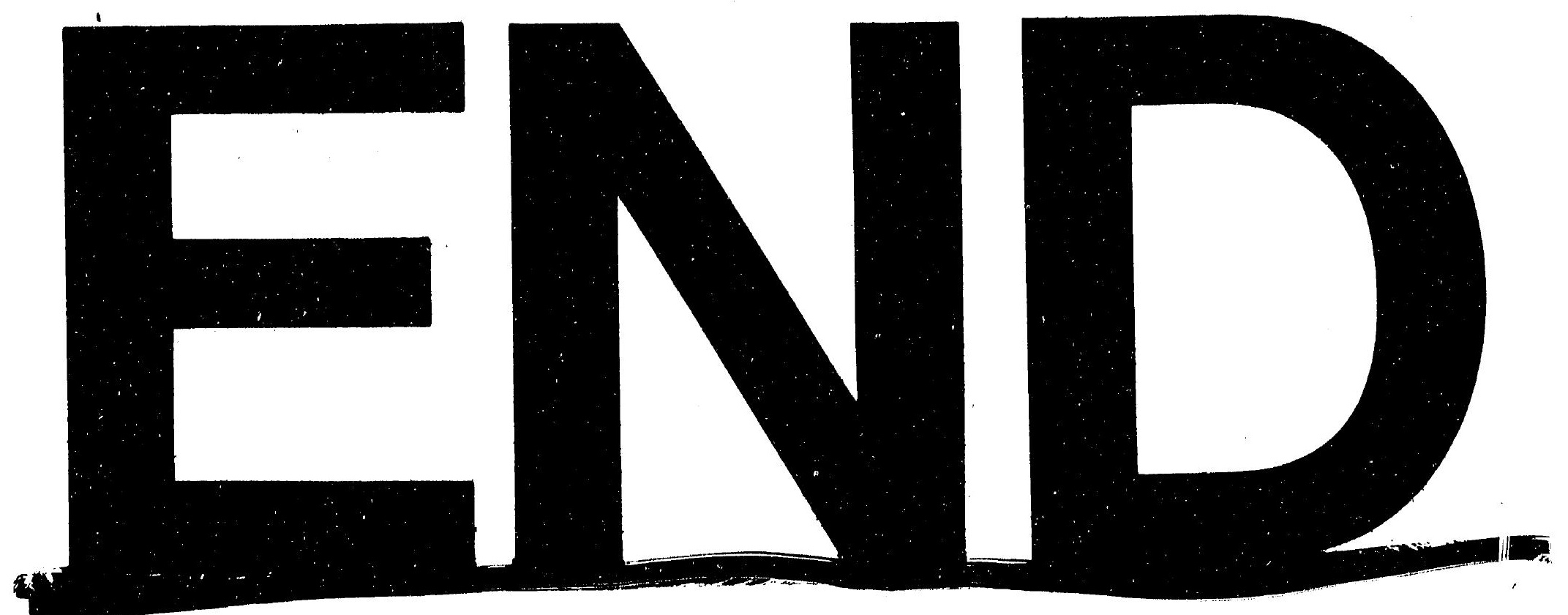

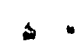
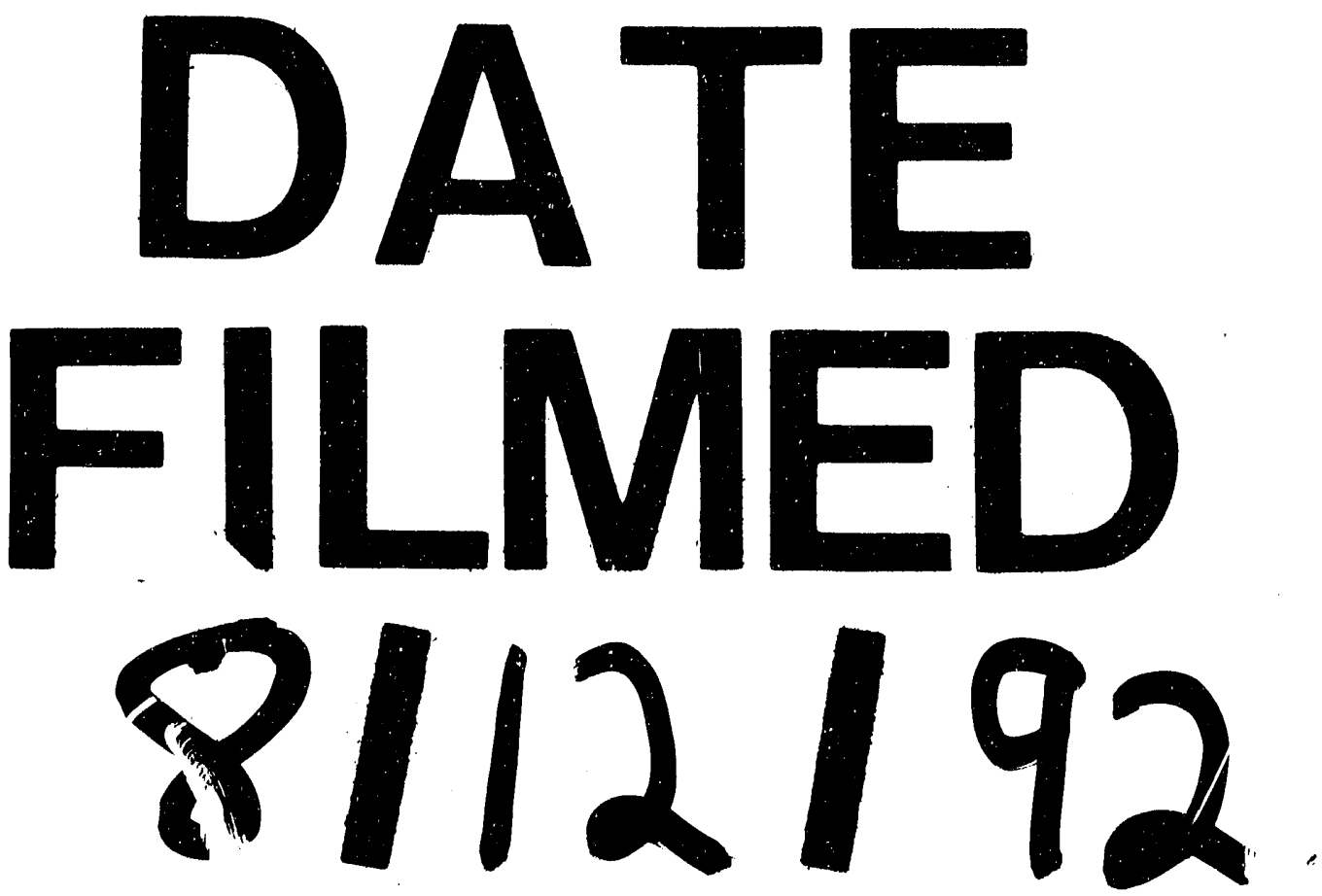


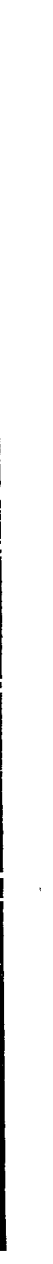

